\title{
Development of a Hybrid Compressor/Expander Module for Automotive Fuel Cell Applications
}

\author{
Final Technical Report for the U.S. Department of Energy \\ Grant Number DE-FC36-01AL67603 \\ Reporting Period \\ $10 / 01 / 2001$ to $09 / 30 / 2004$ \\ DOE Project Officer: Patrick Davis \\ TIAX Project Director: Paul McTaggart \\ Phone Number: 617-498-5847 \\ Fax Number: 617-498-7275 \\ E-Mail: mctaggart.p@tiaxllc.com
}

December 23, 2004

Report prepared by: Paul McTaggart

TIAX LLC

15 Acorn Park

Cambridge, MA

02140-2390

TIAX Reference: D0037

This report was prepared as an account of work sponsored by an agency of the United States Government. Neither the United States government nor any agency thereof, or any of its contractors/subcontractors, or any of their employees, makes any warranty, express or implied, or assumes any legal liability or responsibility for the accuracy, completeness, or usefulness of any information, apparatus, product, or process disclosed, or represents that its use would not infringe privately owned rights. Reference herein to any specific commercial product, process, or service by trade name, trademark, manufacturer, or otherwise, does not necessarily constitute or imply its endorsement, recommendation, or favoring by the United States Government or any agency thereof. The views and opinions of authors expressed herein do not necessarily state or reflect those of the United States Government or any agency thereof. 


\section{Table of Contents}

\begin{tabular}{|c|c|}
\hline $\mathbf{0}$ & XECUTIVE SUMMARY \\
\hline & INTRODUCTION \\
\hline 2.1 & ER MOdule (CEM) \\
\hline 2.2 & NDER MODULE (CEM).. \\
\hline 2.3 & 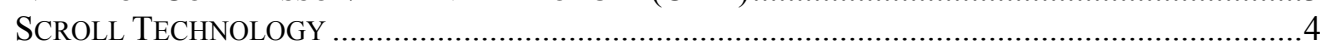 \\
\hline 2.4 & UMMARY OF PRIOR WORK \\
\hline & PROGRAM PLAN... \\
\hline 3.1 & TECHNICAL PLAN.. \\
\hline 3.2 & PROGRAM ORGANIZATION ... \\
\hline 3.3 & COST SHARING. ................................. \\
\hline 3.4 & PROGRAM SCHEDULE..... \\
\hline 0 & HYBRID CEM DESIGN ......... \\
\hline 4.1 & DESIGN APPROACH .. \\
\hline 4.2 & BREADBOARD TESTING... \\
\hline 4.3 & SYSTEM ARCHITECTURE DEVELOPMENT . \\
\hline 4.4 & TURBOMACHINERY DE \\
\hline 4.4.1 & Turbomachine Configurations \\
\hline 4.4 .2 & Turbomachine Design Details.. \\
\hline 4.5 & SCROLL DESIGN .......... \\
\hline 4.5.1 & Concept Generation .. \\
\hline 4.5 .2 & Preliminary Design ..... \\
\hline 4.5 .3 & Technical Risk Assessment ................... \\
\hline 4.5.4 & Downselect Process .. \\
\hline 4.5 .5 & Single Orbiting Scroll.. \\
\hline 4.6 & INTERCC \\
\hline 4.7 & CONTROL AND DATA MANAGEMENT ......... \\
\hline 4.8 & FABRICATION OF BRASSBOARD DRIVE MECHANISM.......... \\
\hline 4.9 & STOP WORK ORDER \\
\hline & 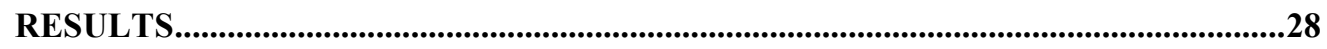 \\
\hline & ........30 \\
\hline & \\
\hline
\end{tabular}




\section{List of Tables}

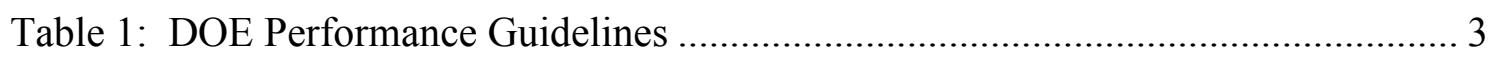

Table 2: Hybrid CEM Program Roles and Responsibilities ............................................... 9

Table 3: Key Envelope Performance Goals.......................................................... 11

Table 4: Comparison of Scroll Configurations …………........................................... 21

Table 5: Results of Technical Risk Assessment …………........................................... 22

Table 6: Scroll Configuration Decision Matrix ……………………………………..... 23

Table 7: Comparison with DOE Guidelines - Compressor Performance ....................... 28

Table 8: Comparison with DOE Guidelines - Expander Performance ............................ 29

Table 9: Comparison with DOE Guidelines - Overall Performance .............................. 29

\section{List of Figures}

Figure 1: Scroll Technology Principle of Operation ................................................... 5

Figure 2: Hybrid CEM Program Flowchart............................................................... 7

Figure 3: Hybrid CEM Development Team ............................................................... 9

Figure 4: Scroll CEM Program Schedule ................................................................... 10

Figure 5: Second Generation Scroll Compressor/Expander Module ........................... 11

Figure 6: Breadboard Version of Hybrid CEM Configuration ...................................... 12

Figure 7: Original System Architecture of Hybrid CEM ............................................ 13

Figure 8: System Architecture of Hybrid CEM - with Bypass Valve ........................... 14

Figure 9: Concepts NREC Baseline Turbocharger Design .......................................... 15

Figure 10: Turbocompressor Configurations Considered during Program ..................... 16

Figure 11: Analysis of Variable Geometry Compressor and Turbine............................. 17

Figure 12: Analysis of Turbocompressor with Wastegate ............................................. 18

Figure 13: Analysis of Turbocompressor with Bypass Valve........................................ 19

Figure 14: Turbocompressor Design for Hybrid CEM ………..................................... 20

Figure 15: Three Alternate Scroll Compressor Preliminary Design Configurations ..... 21

Figure 16: Solid Model of Single Orbiting Scroll ......................................................... 24

Figure 17: Selected Automotive Intercooler ................................................................ 25

Figure 18: Test Fixture for Brassboard Drive Mechanism......................................... 26

Figure 19: TIAX CNC Machining Center and CMM Inspection Machine..................... 27 


\subsection{Executive Summary}

This document summarizes the work performed under the Department of Energy (DOE) contract number DE-FC36-01AL67603 by TIAX LLC. This cooperative agreement contract was directed at advancing the development of an advanced technology compressor/expander for supplying compressed air to Proton Exchange Membrane (PEM) fuel cells in transportation applications. The project built on the work of DOE contract number DE-AC08-96NV11982, during which a first generation scroll compressor/expander prototype was developed, and DOE contract number DE-FC0297EE50487 during which a second generation scroll compressor/expander prototype was developed.

Traditionally, high-speed turbomachinery technology, such as that used in automotive turbochargers, has resulted in a compact high-speed package that delivers high efficiency at the design point, but with performance that falls off dramatically under off-design conditions. Scroll technology, a type of positive displacement machinery, provides high efficiency across a broad range of operating conditions, but results in a package that is significantly larger and heavier than that of high-speed turbomachinery technology.

The overall objective of this program was to develop a hybrid compressor/expander module, based on both scroll and high-speed turbomachinery technologies, which will combine the strengths of each technology to create a concept with superior performance at minimal size and cost. The resulting system is expected to have efficiency and pressure delivery capability comparable to that of a scroll-only machine, at significantly reduced system size and weight when compared to scroll-only designs.

The specific objectives of the program are listed below:

- Design and build a hybrid compressor/expander module using both turbomachinery and scroll compression technology, based on the experience of two previous generations of scroll-based compressor/expander modules developed with DOE.

- Develop the algorithms and hardware to ensure stable and effective control of the hybrid system.

- Deliver a system with equivalent thermodynamic performance, at significantly lower weight and volume, when compared to previous generations of scroll compressor/expander modules.

Based on detailed designs of the critical system elements, the Hybrid Compressor/Expander Module (CEM) concept was projected to deliver significant improvements in weight, volume and manufacturing cost relative to previous generation systems. Additional work was planned to finalize the design of the scroll compressor and turbomachinery and subsequently to fabricate hardware to demonstrate the performance of the Hybrid CEM concept, however, the program could not continue to that point as the program funding was terminated by DOE. 


\subsection{Introduction}

\subsection{Hybrid Compressor/Expander Module (CEM)}

This document summarizes the work performed under the Department of Energy (DOE) contract number DE-FC36-01AL67603 by TIAX LLC. This cooperative agreement contract was directed at advancing the development of an advanced technology compressor/expander for supplying compressed air to Proton Exchange Membrane (PEM) fuel cells in transportation applications. The project built on the work of two prior programs; DOE contract number DE-AC0896NV11982, during which a first generation scroll compressor/expander prototype was developed, and DOE contract number DE-FC02-97EE50487 during which a second generation scroll compressor/expander prototype was developed. These two prior programs were performed by the Technology and Innovation group of Arthur D. Little, Inc. In May 2002, this group was spun off as an independent company, TIAX LLC, and the contract for this program novated to TIAX. Many of the team members of this most recent program were also participants in the two prior programs, resulting in continuity among all three programs.

The results of the developments during the previous two contracts are documented in the final report "Advanced Fuel Cells for Transportation Applications (Development of a Compressor/Expander for Fuel Cells in Transportation Applications)" (Reference 1) and "Development of a Second Generation Scroll Compressor/Expander Module for Automotive Fuel Cell Applications" (Reference 2). Within this report the designs developed under the previous two contracts will be referred to as the First Generation CEM and Second Generation CEM respectively, and the current cooperative agreement will be referred to as the Hybrid CEM.

The Hybrid CEM was designed to provide compressed air over the flow and pressure ranges required for the operation of $50 \mathrm{~kW}$ PEM fuel cells in transportation applications. The performance guidelines for the CEM are outlined in Table 1. Use of an integrated expander allows recovery of energy from the pressurized air exhaust stream, to enhance the overall efficiency of the pressurized air supply system. 
Table 1: DOE Performance Guidelines

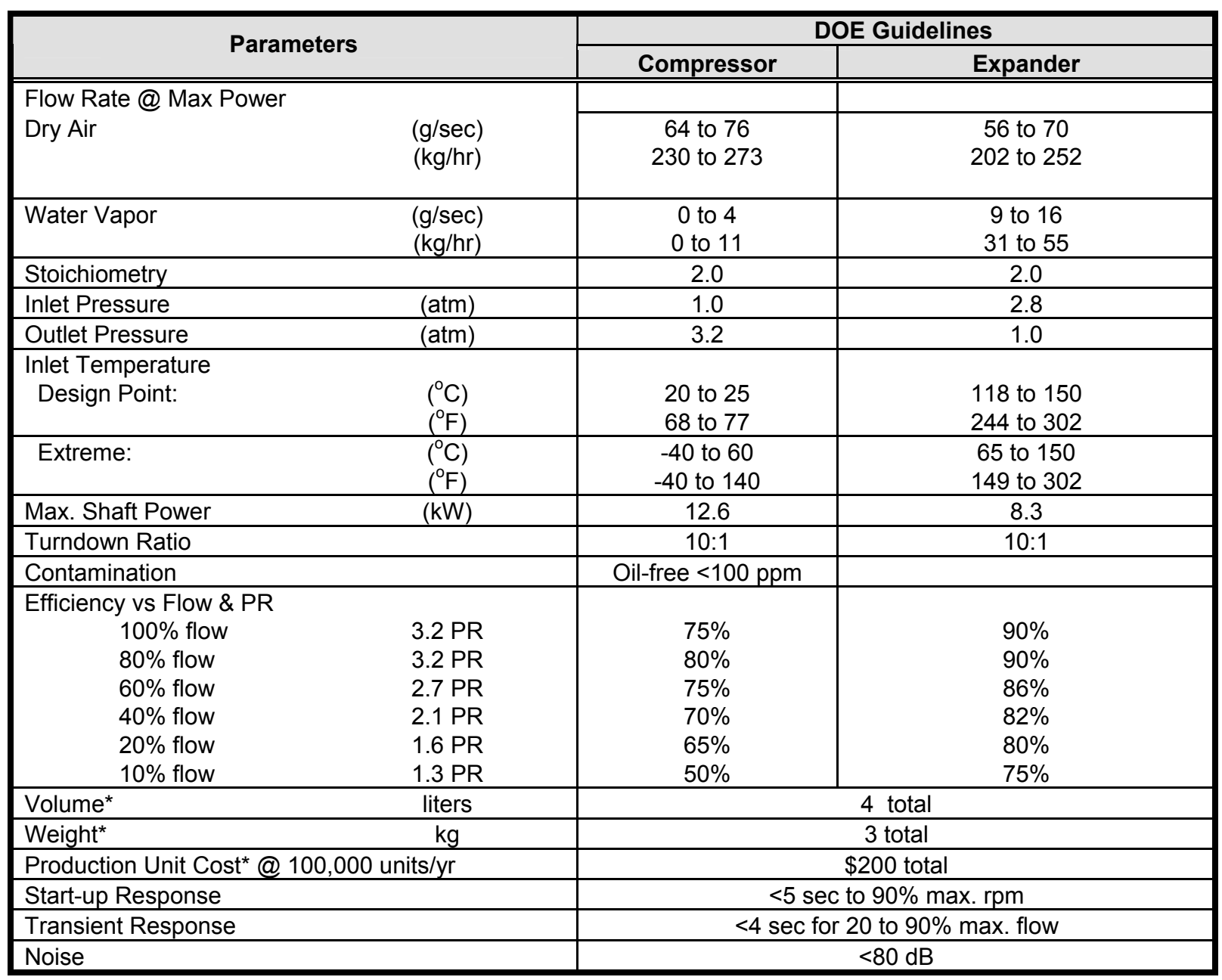

*These values do not include heat exchangers or motors/controllers, however sizing trade-off studies should target minimization of the overall air supply subsystem

\subsection{Need for Compressor/Expander Module (CEM)}

Most Proton Exchange Membrane Fuel Cell (PEMFC) systems currently under development for automotive applications operate under pressurized conditions, usually about 3 atmospheres. This pressure has been selected to reduce stack/fuel processor subsystem volume, improve stack performance, and facilitate water management. However, achieving high levels of system performance at those pressures requires the development of high efficiency compressors, as well as high efficiency expanders to recover energy from the fuel cell exhaust streams. The design and operation of these subsystems is complicated by their need for simultaneously achieving high full and part load efficiency, operation without lubrication in the working spaces, operation over a 10:1 flow range, and compact size. No commercially available equipment meets this combination of requirements, particularly at the pressure ratio of $3: 1$ associated with current design strategies. 
Compressor/expander systems could be the defining element when fuel cell power systems are compared with other options for advanced vehicle power systems, as they may impact system efficiency by $5-7 \%$, weight by up to $1-2 \mathrm{~kg} / \mathrm{kW}$, and cost by $\$ 5-10 / \mathrm{kW}$. Unless all elements are simultaneously optimized at the appropriate pressure level, fuel cell competitiveness will suffer.

Traditionally, high-speed centrifugal technology, such as that used in automotive turbochargers, has resulted in a compact high-speed package that delivers high efficiency at the design point, but with performance that falls off dramatically under off-design conditions. Scroll technology, a type of positive displacement machinery, provides high efficiency across a broad range of operating conditions, but results in a package that is significantly larger and heavier than that of high-speed centrifugal technology.

The objective of this program is to develop a hybrid compressor/expander module, based on both scroll and high-speed centrifugal technologies, which will combine the strengths of each technology to create a concept with superior performance at minimal size and cost. The resulting system is expected to have efficiency and pressure delivery capability comparable to that of a scroll-only machine, at significantly reduced system size and weight when compared to scrollonly designs.

\subsection{Scroll Technology}

TIAX LLC (previously the Technology and Innovation group of Arthur D. Little, Inc.) has been involved in the development of scroll compressor and expander technologies for over 30 years. TIAX LLC is the leading independent research organization worldwide in the development of high efficiency scroll technology. Scroll technology has been incorporated into millions of compressors sold by TIAX LLC licensees throughout the world, primarily in air conditioning and air compressor applications. Recent developments have addressed dry air compression and high temperature scroll expanders for use in small Brayton cycle engines.

Scroll compression is illustrated in Figure 1 below. The compressor consists of two spiralshaped sheets, or "scrolls", which are interleaved to provide chambers enclosing volumes of gas. As the two scrolls orbit relative to each other the chambers spiral inward, contracting as the orbit progresses. These chambers provide the compression of the gas. In a scroll expander, the relative orbiting motion is reversed, and the gas chambers spiral outward. The compressor (or expander) has a built-in volume ratio and is designed such that the state of the gas follows as closely as possible the ideal pressure/volume curve for reversible compression (or expansion). This is one of the key attributes which makes scroll technology highly efficient. 


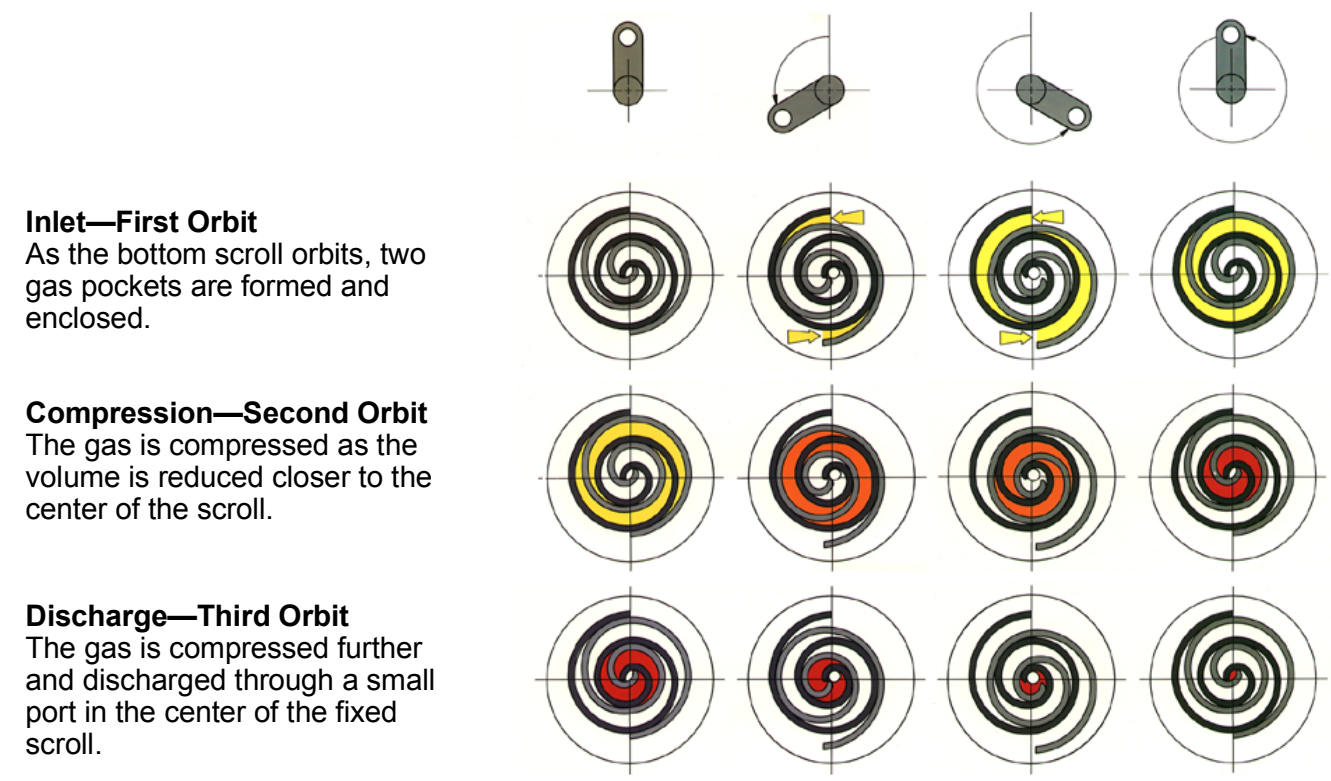

Figure 1: Scroll Technology Principle of Operation

\subsection{Summary of Prior Work}

The work of the First and Second Generation CEMs consisted of the design, fabrication, and testing of three prototypes, representing two successive generations of the CEM design. The work consisted of the following tasks:

\section{First Generation CEM:}

- Design and analyses to establish suitable component designs

- Critical component evaluations to establish refined component designs and the design for the prototype integrated compressor/expander

- Prototype compressor/expander fabrication and qualification testing

- Progressive hardware modifications and upgrades based on test results.

\section{Second Generation CEM:}

- Fabrication of a second prototype of the first generation design for additional testing.

- Testing of the first generation prototypes to evaluate options for design modifications and to demonstrate reliability with increased testing hours.

- Design of the second generation prototype.

- Key-component tests to validate the second generation design.

- Fabrication of the second generation prototype and qualification testing.

- Integration of the scroll CEM in a fuel cell system for integrated system testing. This work was done in collaboration with Energy Partners. 
The results of the Second Generation CEM concluded that scroll technology is a very promising option for CEMs suitable for 50-kW Fuel Cells. The flow capacity, pressure delivery, performance range, high efficiency, acceptable noise, and reasonable projected cost of the Second Generation scroll CEM validated that scroll technology is a viable option for this application. The flow capacity of the Second Generation CEM was roughly double that of the First Generation unit, providing sufficient flow for a $50-\mathrm{kW}$ fuel cell system. It also has improved capability to handle fuel cell pressure drop and for maintaining high delivery pressure at low flow rate, due to the rolling element bearing design approach. Efficiency, noise, and projected cost are comparable to that of the First Generation unit. The scroll CEM is equal to or better than competing technologies in performance, efficiency, and cost.

Although the performance of the scroll CEM was proven to meet the DOE guidelines, the size and weight of the Second Generation Scroll CEM were about 10 times the DOE Guideline targets of $3 \mathrm{~kg}$ and 4 liters respectively. These very aggressive targets are probably not feasible for any positive displacement CEM, and possibly will never be met by any technology. While the potential exists for some reduction of the size and weight of the scroll CEM through speed increase, this would not be sufficient to meet the DOE targets and would also result in reduced efficiency, greater noise, and decreased lifetime. Additional size and weight reductions are possible without significant speed increase, but not the order-of-magnitude reduction which is targeted.

At the conclusion of the Second Generation CEM program, it was felt that significant reduction of size and weight with a CEM that continues to exhibit the performance and efficiency advantages of scroll technology may be possible with a Hybrid CEM which incorporates a scroll compressor and a turbine-driven high-speed-centrifugal compressor. This concept was proposed to DOE, and the resulting development program is the subject of this report. 


\subsection{Program Plan}

\subsection{Technical Plan}

The overall objective of this program is to develop a hybrid compressor/expander module, based on both scroll and high-speed turbomachinery technologies, which will combine the strengths of each technology to create a concept with superior performance at minimal size and cost.

The specific objectives of the program are listed below:

- Based on the experience of two previous generations of scroll-based compressor/expander modules developed with DOE, design and build a hybrid compressor/expander module using both turbomachinery and scroll compression.

- Develop the algorithms and hardware to ensure stable and effective control of the hybrid system.

- Deliver a system with equivalent thermodynamic performance, at significantly lower weight and volume, when compared to previous generations of scroll compressor/expander modules.

The program plan to accomplish these objectives is outlined below. The overall system architecture was developed first. This established the design parameters for each of the three subsystems: the scroll compressor, the turbomachine, and the controller and auxiliary system equipment. These design parameters included the inlet and outlet gas conditions and physical interfaces between subsystems. Once this overall architecture was defined, the development of each subsystem occurred in parallel, including the detailed design of each subsystem.

Fabrication and test of each subsystem was planned, but not completed because the funding to the program was terminated. Once the development of each subsystem had been completed and verified by test, the subsystems were to be integrated together into the Hybrid CEM system. The program would then conclude with extensive system testing to map the performance of the CEM. This process is illustrated in Figure 2.

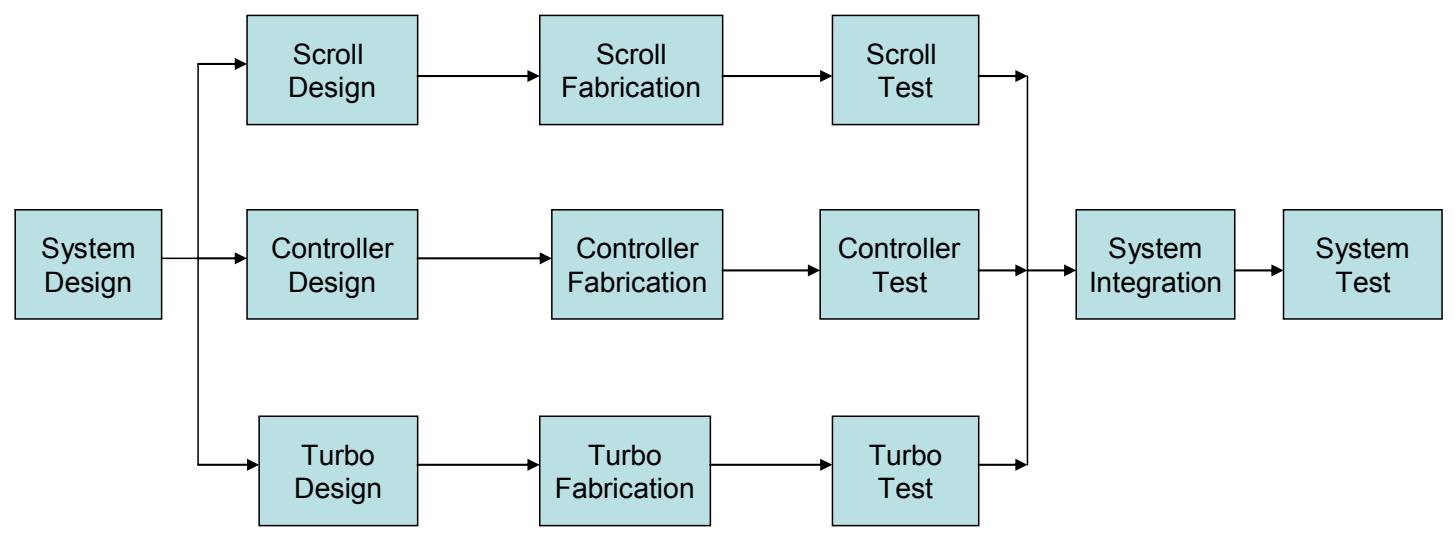

Figure 2: Hybrid CEM Program Flowchart

The development tasks outlined above were phased to occur over a three year program as follows: 
- In the first year, develop system architecture and subsystem designs consistent with the overall goals of maintaining thermodynamic performance while reducing weight and volume relative to previous generations.

- In the second year, complete detailed engineering and initiate fabrication of subsystem components, and develop the control system hardware and algorithms.

- In the third and final year, complete fabrication of components and conduct subsystem assembly and test, followed by system integration and performance verification.

\subsection{Program Organization}

The Hybrid Scroll CEM program was led by TIAX LLC, the prime contractor, with Scroll Corporation and Concept NREC as subcontractors.

\section{TIAX LLC - Prime Contractor}

TIAX LLC (www.tiaxllc.com) is a leading collaborative product and technology development firm that accelerates innovation to help its clients create an impact in the market--and in people's lives. We integrate business, industry, and hands-on technology expertise to transform ideas into products and problems into solutions. Formed out of Arthur D. Little's Technology \& Innovation business, TIAX builds on more than a century of breakthrough innovation and client success using collaborative R\&D. TIAX was selected as a Technology Pioneer 2003 by the World Economic Forum and is ISO 9001 certified with more than 50 research and development laboratories.

\section{Scroll Corporation - Subcontactor}

Mr. John McCullough, a former Arthur D. Little employee, is the founder of Scroll Corporation. Scroll Corporation was a subcontractor to TIAX LLC under this effort to assist with the design and development of scroll machinery. Mr. McCullough has worked closely with the team members for many years as an Arthur D. Little employee.

\section{Concepts NREC - Subcontractor}

Concepts NREC specializes in the design and development of turbo-machinery and has about 70 years experience in developing advanced turbomachinery to meet demanding commercial and military requirements. Concepts NREC was a subcontractor to TIAX LLC under this effort to assist with the design and development of the turbomachinery.

The organization chart for the Scroll CEM program is presented in Figure 3. A detailed description of the roles and responsibilities of each team member appears in Table 2. The team consisted of experienced mechanical, electrical, and manufacturing engineers and managers that have previously worked together on many successful scroll development programs in the past. 


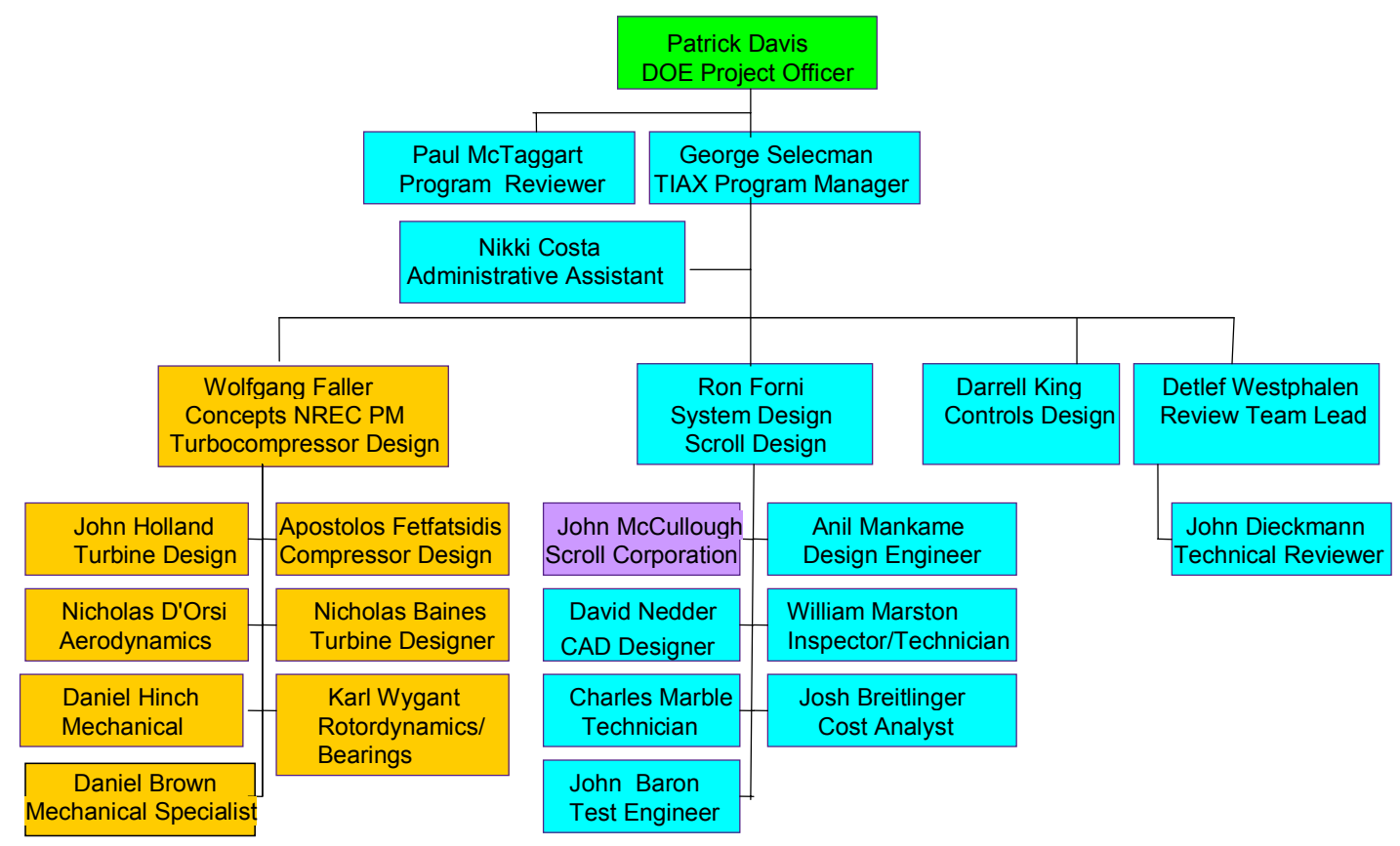

Figure 3: Hybrid CEM Development Team

Table 2: Hybrid CEM Program Roles and Responsibilities

\begin{tabular}{|c|c|c|}
\hline Name & Role(s) & Responsibilities \\
\hline "George Selecman & $\begin{array}{l}\text { Program Manager } \\
\text { System Integration }\end{array}$ & $\begin{array}{l}\text { - Overall responsibility for all aspects of the program } \\
\text { - Coordinate all design, fabrication, and test activities } \\
\text { - Oversee Scroll system design } \\
\text { - Coordinate contract documentation and deliverables }\end{array}$ \\
\hline Paul McTaggart & Program Reviewer & $\begin{array}{l}\text { - Oversee program execution } \\
\text { - Ensure PM has adequate resources } \\
\text { - Monitor program quality }\end{array}$ \\
\hline $\begin{array}{l}\text { Detlef Westphalen } \\
\text { John Dieckmann }\end{array}$ & $\begin{array}{l}\text { Technical Reviewer } \\
\text { System Analysis/ } \\
\text { Requirements }\end{array}$ & $\begin{array}{l}\text { - Oversee technical performance } \\
\text { - Provide input to system requirements evaluation }\end{array}$ \\
\hline Ronald Forni & $\begin{array}{l}\text { Scroll CEM Design and } \\
\text { Fabrication } \\
\text { System Test \& Evaluation }\end{array}$ & $\begin{array}{l}\text { - Thermal and structural analysis including FEA } \\
\text { - Assist in Scroll design and performance analysis } \\
\text { - Drawing package production } \\
\text { - Supervise fabrication and assembly } \\
\text { - Supervise day-to-day testing } \\
\text { - Oversee system testing and evaluation }\end{array}$ \\
\hline Anil Mankame & Design Engineer & $\begin{array}{l}\text { - Perform detail analyses to validate designs } \\
\text { - Perform trade studies on design alternatives }\end{array}$ \\
\hline John Baron & $\begin{array}{l}\text { Scroll CEM Fabrication } \\
\text { System Test and } \\
\text { Evaluation }\end{array}$ & $\begin{array}{l}\text { - } \text { Design, fabricate, and modify test equipment } \\
\text { - Assist performance testing } \\
\text { - Assist in Scroll fabrication and assembly }\end{array}$ \\
\hline $\begin{array}{l}\text { John McCullough } \\
\text { (Scroll Corporation) }\end{array}$ & $\begin{array}{l}\text { Scroll CEM Design } \\
\text { Component Testing }\end{array}$ & $\begin{array}{l}\text { - Primary responsibility for design of Scroll CEM } \\
\text { - Implement design modifications/improvements }\end{array}$ \\
\hline $\begin{array}{l}\text { Wolfgang Faller } \\
\text { (Concepts NREC) }\end{array}$ & $\begin{array}{l}\text { Manager - } \\
\text { Turbomachinery Design } \\
\text { and Component Testing }\end{array}$ & $\begin{array}{l}\text { - Primary responsibility for design of Turbomachinery } \\
\text { - Implement design modifications/improvements }\end{array}$ \\
\hline
\end{tabular}




\subsection{Cost Sharing}

The TIAX LLC team shared the cost of the Hybrid CEM program with the Department of Energy, by providing funding for twenty-five percent of the cost of the program. Both Concepts NREC and Scroll Corporation, our major subcontractors on the program, contributed to the cost sharing by funding twenty-five percent of the work that they performed respectively.

\subsection{Program Schedule}

The project schedule, showing all tasks and key milestones, is shown in Figure 4 below. The schedule was modified from the original schedule due to reduced funding by DOE, and as a result was stretched in order to meet the yearly funding available.



${ }^{*}$ As necessary; within 5 calendar days after events

Figure 4: Scroll CEM Program Schedule 


\subsection{Hybrid CEM Design}

\subsection{Design Approach}

The design approach for the Hybrid Compressor/Expander Module (CEM) builds on the experience gained from developing the first two generations of scroll CEMs, in combination with the substantial experience of our turbomachinery subcontractor, Concepts NREC. Figure 5 shows the Second Generation Scroll CEM on its test stand.

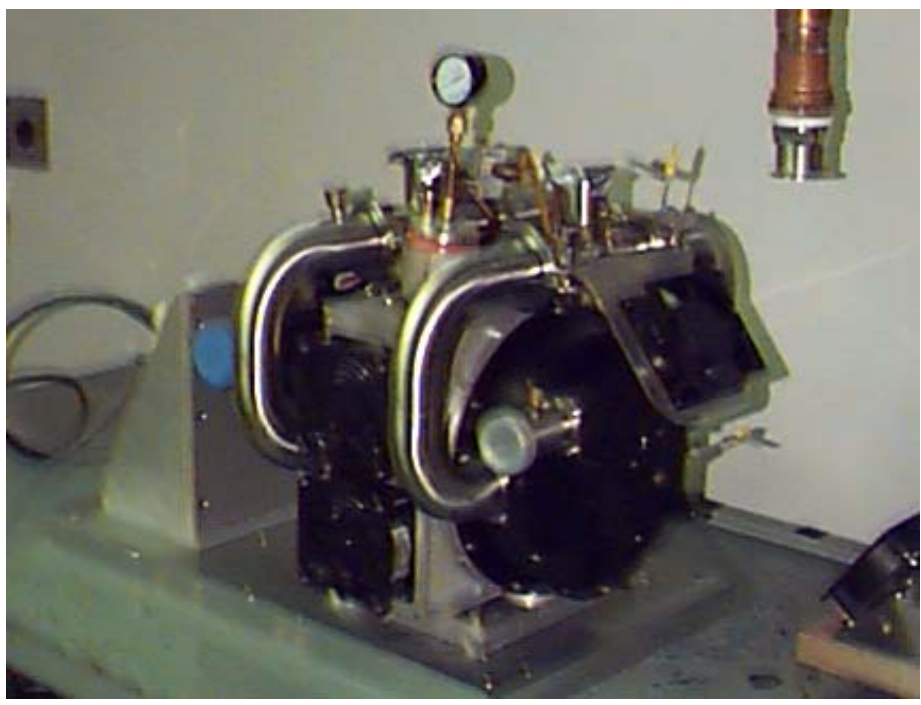

Figure 5: Second Generation Scroll Compressor/Expander Module

By combining the performance attributes of a positive displacement scroll compressor (electrically driven) with those of a turbocharger (driven by fuel cell exhaust gases), we expected to be able to very closely match the pressure/flow requirements of the DOE guidelines in a package that is smaller and lighter than previous generations. Table 3 shows the weight and volume design goals for the program; with acknowledgement that these goals are still somewhat short of the DOE guidelines, they are clearly an improvement over the Second Generation system.

Table 3: Key Envelope Performance Goals

\begin{tabular}{|l|c|c|c|c|c|}
\hline \multirow{2}{*}{ Parameter } & \multicolumn{4}{|c|}{ Hybrid } & $\begin{array}{c}\text { Second } \\
\text { Generation } \\
\text { Scroll CEM }\end{array}$ \\
\cline { 2 - 6 } & Turbocharger & Scroll & Motor & Total & 12 \\
\hline Diameter (in) & 6 & 7 & 7 & 7 & 20 \\
\hline Length (in) & 5 & 8 & 5 & 18 & 30 \\
\hline Bulk volume (I) & 2.3 & 5 & 10 & 37 & 90 \\
\hline Weight (lb) & 10 & 17 & 3 & \\
\hline
\end{tabular}




\subsection{Breadboard Testing}

Prior to the start of the Hybrid CEM program, TIAX completed the construction and testing of a breadboard model of the system, as shown in Figure 6. In this configuration, a conventional automotive turbocharger (in the foreground) was coupled to the scroll compressor portion of the First Generation CEM (in the background). The results of that preliminary exploratory testing, while not delivering the desired efficiency, were sufficiently promising to justify the system concept.

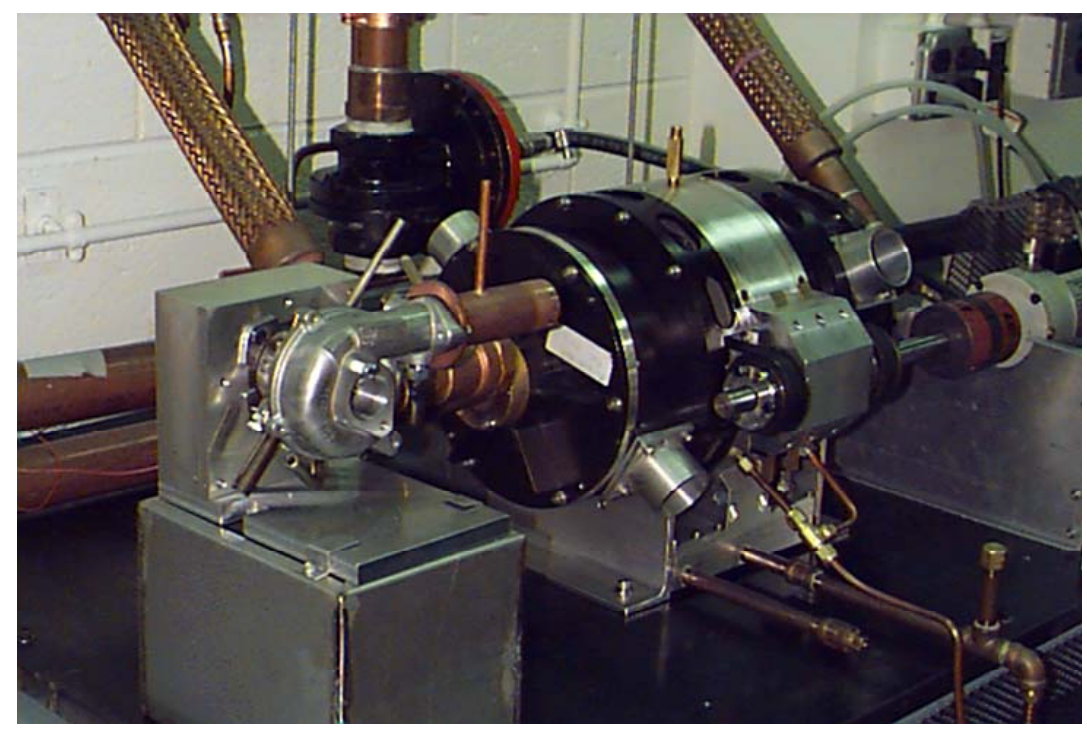

Figure 6: Breadboard Version of Hybrid CEM Configuration

\subsection{System Architecture Development}

The initial effort to develop appropriate system architecture resulted in the block diagram shown in Figure 7. In this configuration, the turbocompressor draws in ambient air, and compresses it to an intermediate pressure. (Note that the specification of this intermediate pressure is a key element in assigning performance requirements to the subsystems). In order to reduce both the size and operating temperature of the scroll compressor, an intercooler is provided to reject at least part of the heat of compression to atmosphere. The partially compressed gas, now cooler and denser, is then fed into the scroll compressor, which uses electrical power to achieve the final compression of the gas. Finally, the compressed air is fed into the fuel cell. The exhaust gas from the fuel cell has slightly more mass flow (representing combusted fuel), higher temperature, and slightly reduced pressure ( $0.4 \mathrm{~atm}$ pressure drop is expected according to the DOE guidelines). The exhaust gas drives the turbine (through controllable inlet guide vanes) and, after the bulk of its energy extracted, is exhausted to atmosphere. The turbine provides the shaft power to drive the turbocompressor by direct coupling. 


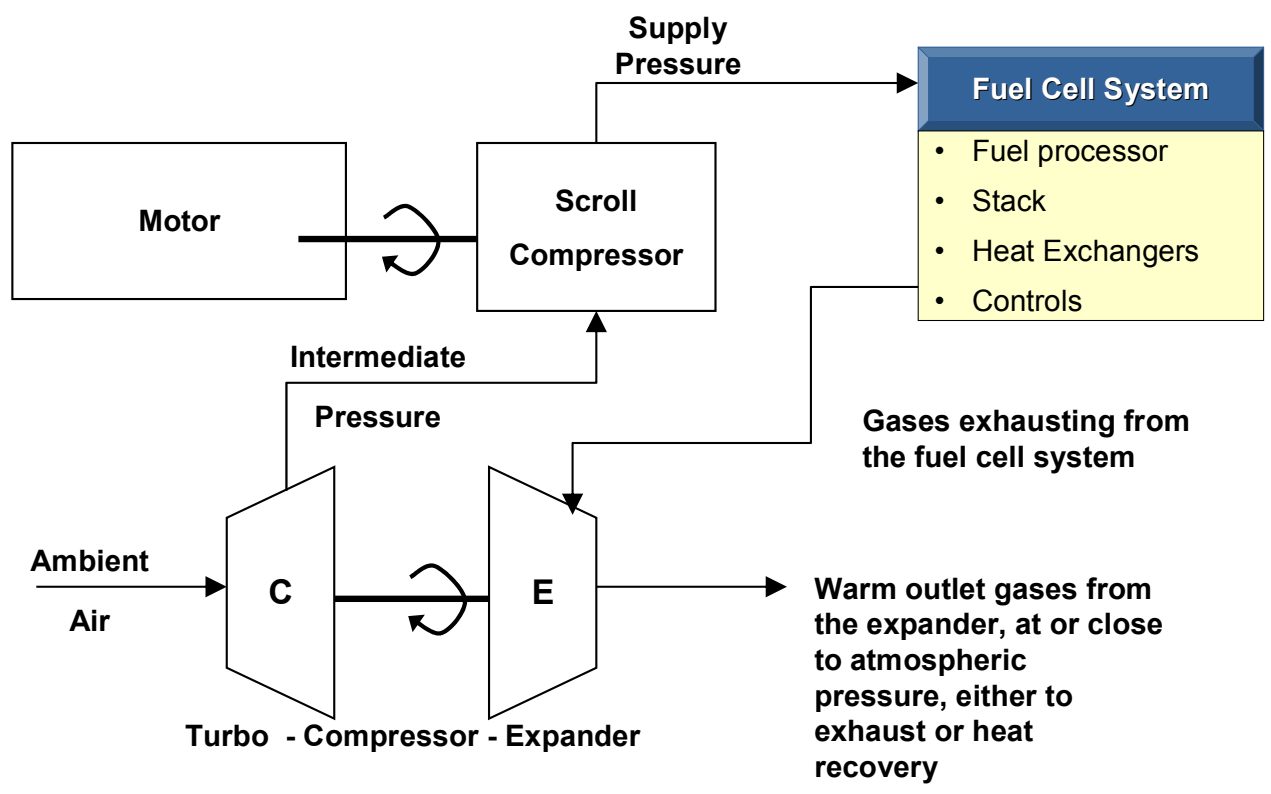

Figure 7: Original System Architecture of Hybrid CEM

This architecture offers some important advantages:

- The turbocompressor is powered only by the turbine, eliminating the issues associated with coupling power into a high-speed rotating shaft

- Turbine inlet guide vanes provide a way to control fuel cell stack pressure while simultaneously maximizing energy recovery.

- The scroll compressor provides pressure/flow characteristics that enable efficient operation across a broad range of flow rates.

Capturing these advantages entails, of necessity, overcoming several design challenges:

- Control of coupled turbomachinery and positive displacement machinery

- Power and waste heat management

- Isolation of lubricants from the process gas stream

- Reduction of size, weight and cost.

As the design effort progressed, the initial system architecture was modified in order to simplify the system and eliminate the inlet guide vanes of the turbocompressor which are costly and complex to control. The System Block Diagram was modified to include an optional bypass valve to redirect flow around the turbine and tailor the pressure/flow profile. This new architecture is shown in Figure 8. 


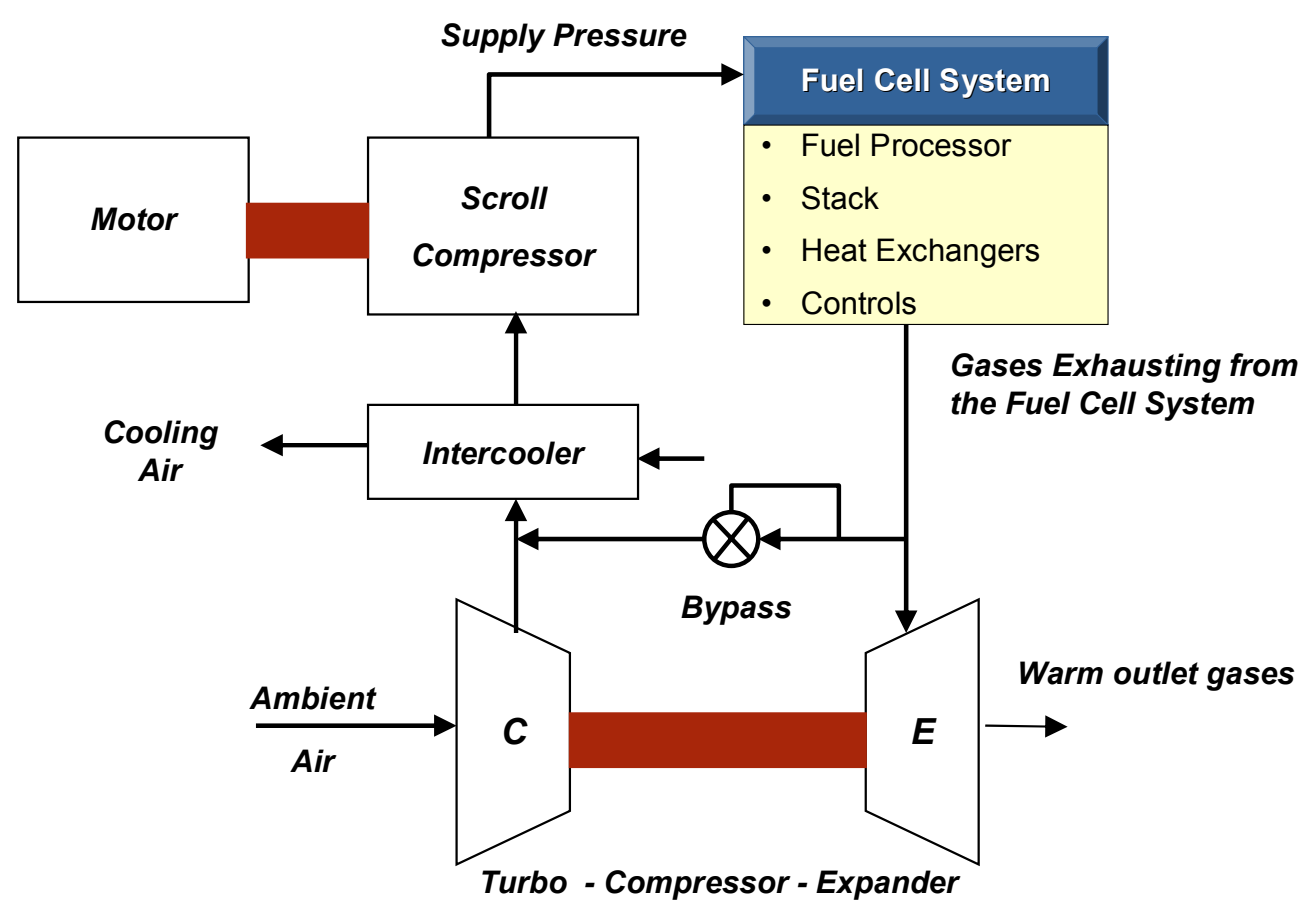

Figure 8: System Architecture of Hybrid CEM - with Bypass Valve

The exhaust gas from the fuel cell drives the turbine and, the bulk of its energy extracted, is exhausted to atmosphere. The turbine provides the shaft power to drive the turbocompressor by direct coupling. This operating mode is used up to a selectable fraction of maximum flow, currently set to approximately $80-90 \%$, at which point a relief valve opens permitting a small fraction of the discharge gas mass flow to bypass the turbine and be fed directly into the intercooler inlet. With this system feature, the turbomachine is dramatically simplified by eliminating the controllable inlet guide vanes, and its operating range substantially reduced thereby improving its overall efficiency profile.

This architecture offers some important advantages:

- The turbocompressor provides stack operating pressure control by purely passive means, eliminating the need for an active control element and its associated parts, actuator, and control logic,

- The bypass valve permits recapture of a significant fraction of the discharge enthalpy without passing through the turbomachine,

- Recirculation of a fraction of the waste water in the discharge stream into the inflow stream, and

- The scroll compressor provides pressure/flow characteristics that enable efficient operation across a broad range of flow rates.

Capturing these advantages entails, of necessity, overcoming several challenges:

- Overcoming a small oxygen deficit in the in-flowing process gas that results from recirculating a small amount of discharge gas, and

- Managing any possible stack toxins in the discharge stream. 
These challenges were judged to be manageable, and significantly outweighed by the advantages of the reduced cost and complexity of the bypass valve design. As a result, the system architecture with the bypass valve was chosen for the Hybrid CEM.

\subsection{Turbomachinery Design}

The approach to the design of the turbocompressor was to start with an automotive turbocharger, pictured in Figure 9. Although clearly representing an increase in complexity and parts count, controllable inlet guide vanes for the turbine were initially considered a necessary minimum. Similar controls on compressor flow were considered as part of the overall component design tradeoff study. In the interest of simplicity and conventionality, the initial design studies focused on conventionally lubricated roller bearings. Management of the lubricant, though challenging, is considered more tractable than the integration of gas bearings or other technologies.

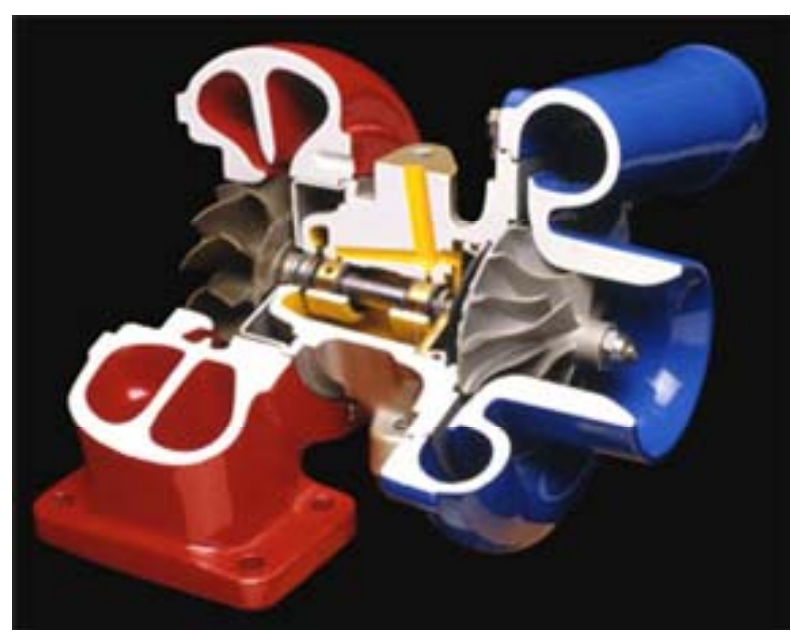

Figure 9: Concepts NREC Baseline Turbocharger Design

\subsubsection{Turbomachine Configurations}

Over a dozen different turbomachine configurations, shown in Figure 10, were considered, exploring the potential for multiple stage and controllable geometry designs to address the performance requirements. Although ultimate performance can only be achieved with controllable guide vanes for the expander and/or compressor, these features add substantially to the cost and complexity of the turbomachine. By exploiting the opportunity to recirculate a small fraction of the discharge gas, a fixed geometry turbomachine can be made to cover the full required performance range 

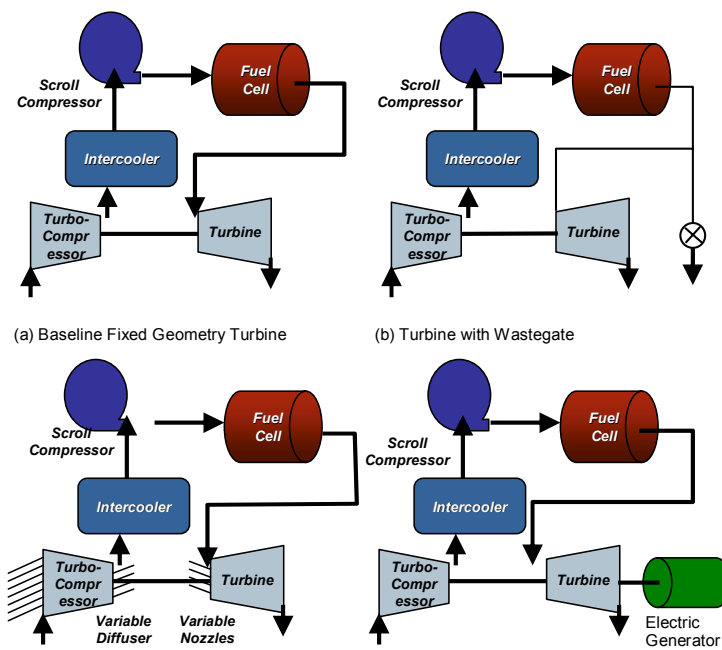

(b) Turbine with Wastegate

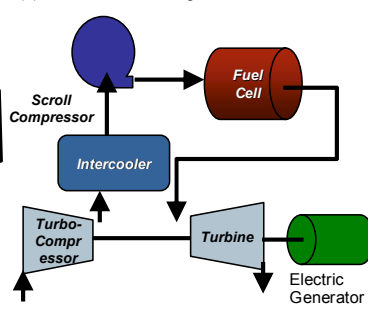

(c) Variable Geometry Turbo-Compressor

(d) Turbine with Turbine-driven Generator
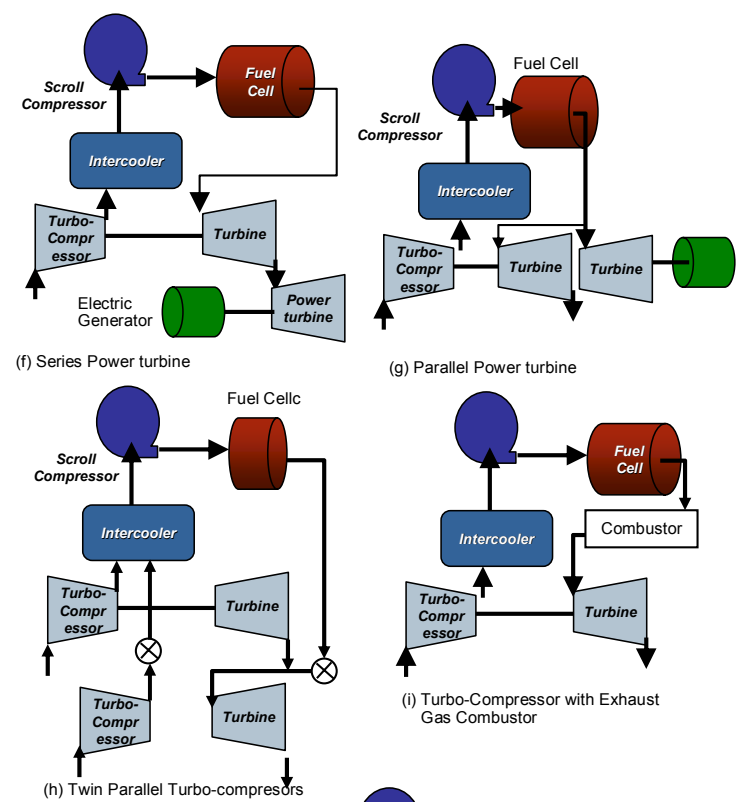

(g) Parallel Power turbine

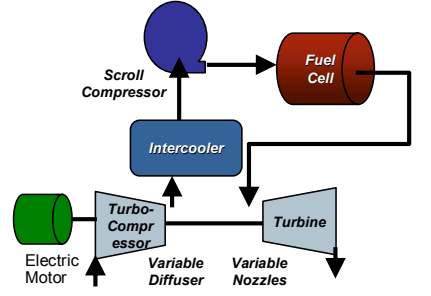

(h) Twin Parallel Turbo-compresớr

(e) Turbo-compressor with Motor Drive to Compressor

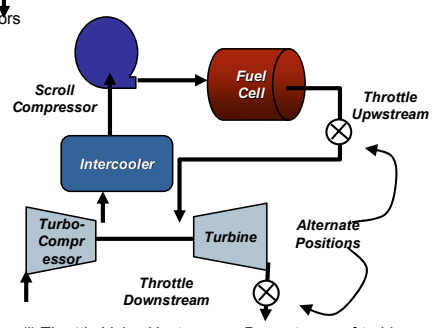

(j) Throttle Valve Upstream or Downstream of turbine

Figure 10: Turbocompressor Configurations Considered during Program 
In an effort to get the most efficient air supply under the constraints governed by the DOE Guidelines, we looked at variable geometries for both the compressor and turbine. Figure 11 contains a schematic representation of this system, along with performance maps resulting from the analysis of the design. The analysis of this system indicated that the variable geometry allows us to maximize efficiency across the flow range of the DOE guidelines. However, because the air flow rate is so low relative to typical automotive turbochargers, the size of the resulting variable guide vanes is much smaller than typical. This small size presents manufacturing difficulties increasing the cost of the turbomachine, as well possibly making the geometry difficult to control. These difficulties led us to look for alternate, simpler methods of controlling air flow.
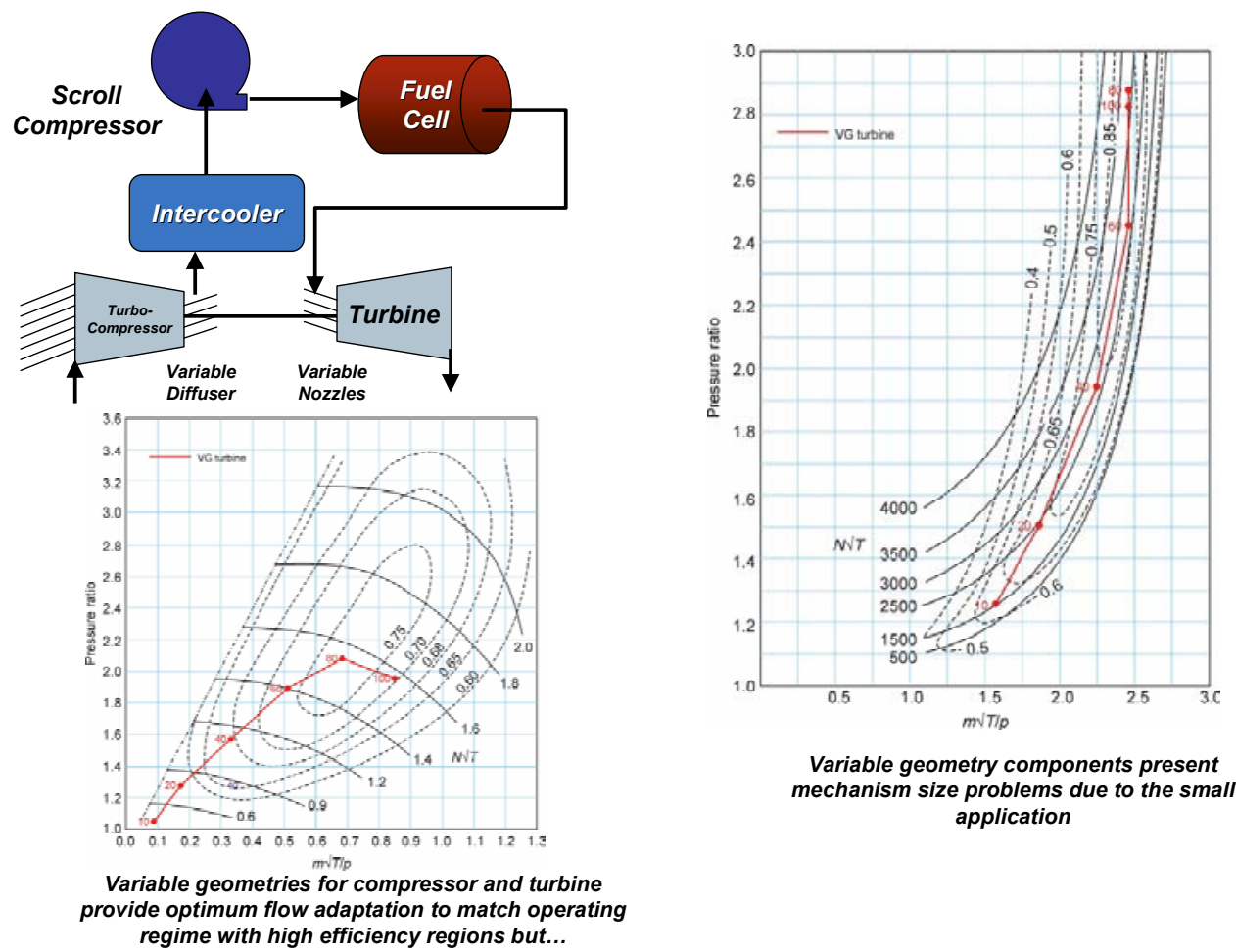

Figure 11: Analysis of Variable Geometry Compressor and Turbine 
A much simpler method of controlling air flow is to use a fixed geometry configuration and incorporate what is known as a wastegate. The wastegate, widely used on automotive turbochargers, is a pressure operated valve which is designed to open at a preset value of pressure, dumping excess flow at pressures above this point. Figure 12 shows a schematic diagram of the system, with the performance maps resulting from the analysis of this configuration. This system would allow us to meet the DOE guidelines at high flow conditions, but would severely compromise performance at other operating points. This system is much less expensive because of the fixed geometry and the simple, passive controls of the wastegate. Despite these cost advantages, it was felt that the negative efficiency impact at certain operating regimes ruled this configuration out.
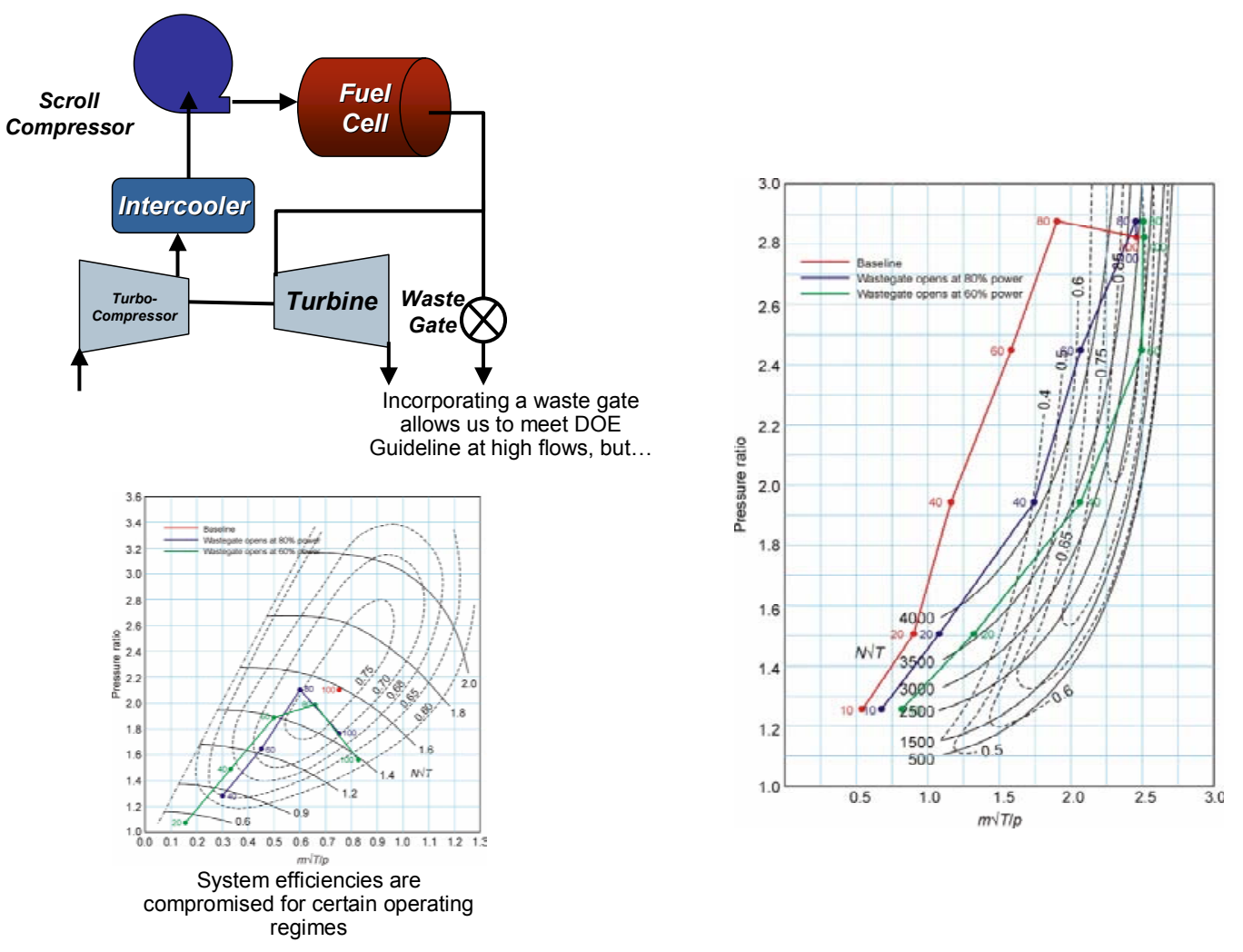

Figure 12: Analysis of Turbocompressor with Wastegate 
Our experience in analyzing these two configurations led us to look for a configuration that would ideally have the efficiency of the variable geometry while maintaining the simplicity of the wastegate system. We felt that if we could recover the bypassed enthalpy by recirculating part of the discharge gas, it could offer important advantages in efficiency. We incorporated a bypass valve into the system which, rather than dumping the excess flow overboard, would direct the flow back into the system at a lower pressure - at the entrance to the intercooler. This allows the enthalpy of the gas, which would be dumped overboard in the wastegate system, to be partially recaptured and recirculated at an intermediate pressure. A schematic representation of this system is presented in Figure 13, along with the performance maps resulting from an analysis of this cycle. With this system feature, the turbomachine is dramatically simplified by eliminating the controllable inlet guide vanes, and its operating range substantially reduced thereby improving its overall efficiency profile.

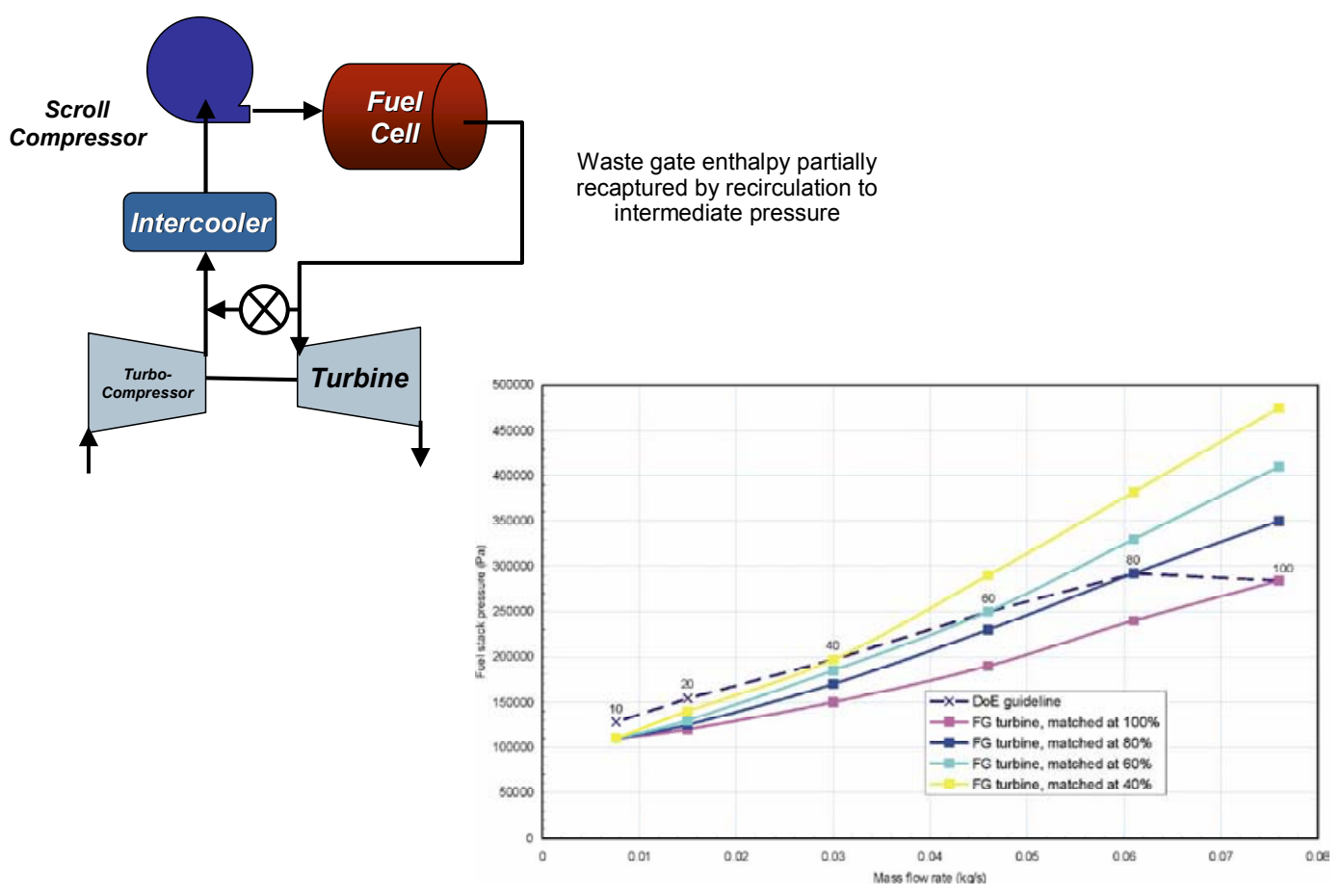

Figure 13: Analysis of Turbocompressor with Bypass Valve

\subsubsection{Turbomachine Design Details}

A detailed design of the turbocompressor for the Hybrid CEMwas completed. This simplified design, adapted from turbocharger technology represents a balance between cost, complexity, performance and risk.A solid model of the design is shown in Figure 14. Key design parameters are as follows:

- Aluminum wheels/housings: 1.7" $\varnothing$ turbine, 2.0" $\varnothing$ compressor

- Operating speed range up to $140,000 \mathrm{rpm}$ 
- Grease lubricated ball bearings: max. speed $150,000 \mathrm{rpm}$. No contamination of gas path

- Steel shaft

- 'Stiff' shaft design (first critical speed $\sim 160,000 \mathrm{rpm}$

- Simple seals (labyrinths)

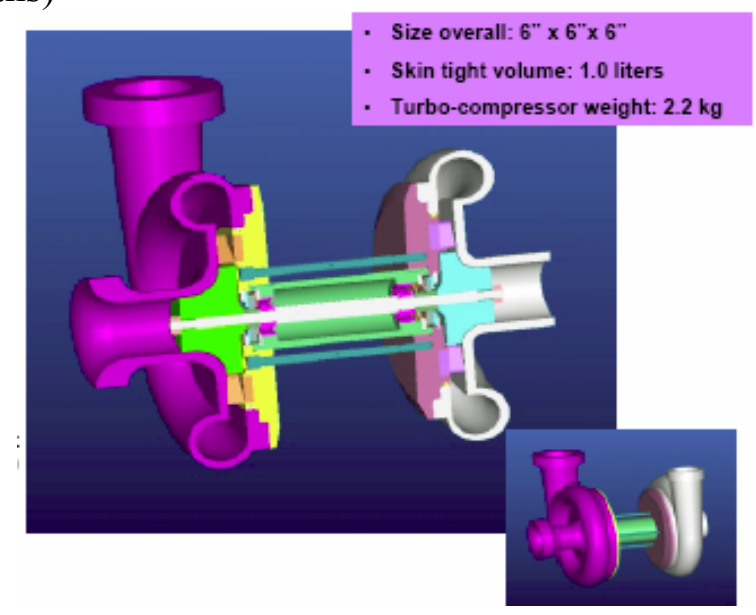

Figure 14: Turbocompressor Design for Hybrid CEM

In the turbocompressor, conventional grease-lubricated ball bearings were identified and selected. Lubricant management was simplified by the relatively low vapor pressure of the selected grease, as well as the physical and pressure-gradient isolation provided in the design of the turbocompressor. Aluminum wheels and housings were designed, and the rotordynamics configured to provide "stiff," or below-resonance, operation over the whole operating range. Estimated maximum turbine efficiencies of $86 \%$, and compressor efficiencies up to $75 \%$, closely approach the targets defined in the DOE guidelines.

\subsection{Scroll Design}

\subsubsection{Concept Generation}

Initially, a number of potential scroll configurations were considered for the Hybrid CEM, including single, back-to-back, and quad orbiting configurations, as well as a co-rotating configuration. After a preliminary analysis of the candidates in this group, a relatively quick downselect to the three most promising alternatives was made. These three scroll configuration options are shown in Figure 15. The first alternative, the Single Orbiting Scroll, was a conventional crank-driven orbiting scroll, supported on a roller-Oldham bearing system and lubricated by grease. This configuration has the substantial advantage of conventionality, enabling the direct utilization of knowledge gained in dozens of scroll compressor design programs. In the second configuration, the Co-rotating Scroll, the two opposing elements of the scroll both rotate, on offset axes, coordinated in such a way that their relative motion is orbital. The primary advantage of this configuration lies in the relatively conventional bearing configuration, offset in part by a relatively unconventional drive mechanism requirement. The third design, the Quad Orbiting Scroll, gangs multiple scrolls on a common drive mechanism, 
offering the possibility of reduced noise with the accompanying penalty of a relatively complex drive mechanism.

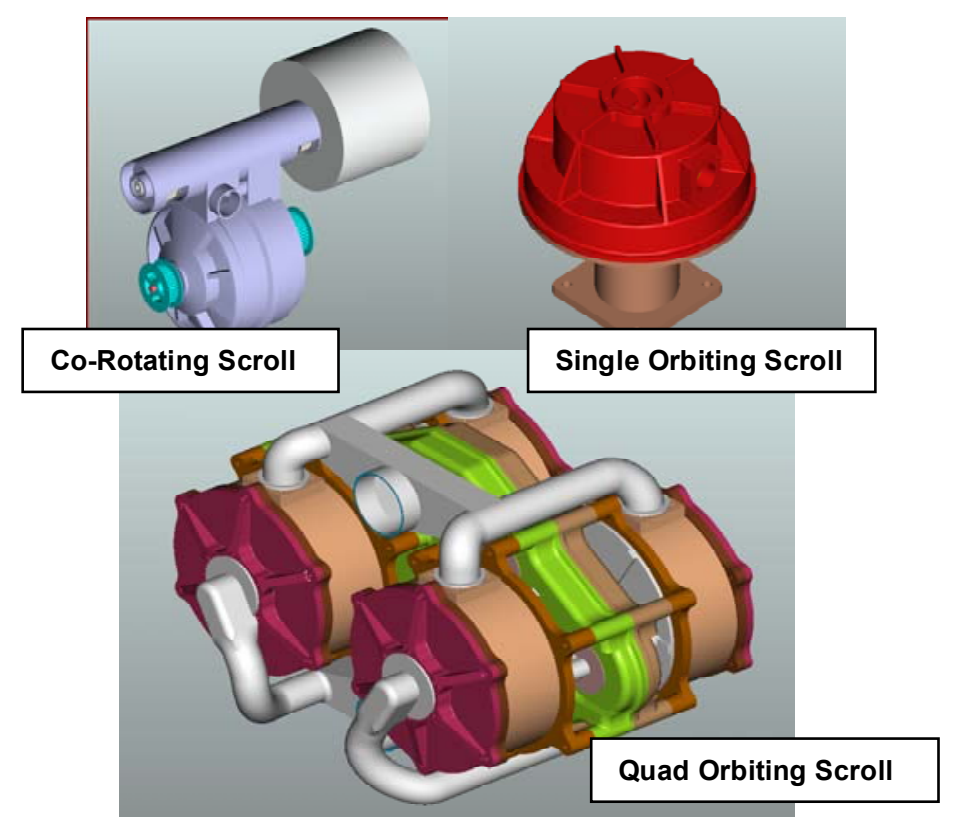

Figure 15: Three Alternate Scroll Compressor Preliminary Design Configurations

\subsubsection{Preliminary Design}

The three alternative configurations for the scroll compressor outlined above were studied in detail, including a preliminary drive system sizing and generation of complete layouts for all three designs. Each configuration was evaluated for size, weight, design speed, efficiency, noise, cost, and technical risk. The results of these analyses appear in Table 4.

Table 4: Comparison of Scroll Configurations

\begin{tabular}{|c|c|c|c|}
\hline $\begin{array}{c}\text { Design } \\
\text { Configurations }\end{array}$ & Single Orbiting Scroll & Quad Orbiting Scroll & Co-Rotating Scroll \\
\hline Maximum Speed & 5,000 rpm or Less & $6,250-7,000 \mathrm{rpm}$ & 6,250 rpm or Higher \\
\hline $\begin{array}{c}\text { Size } \\
\text { (5.0 L goal) }\end{array}$ & $7.2 \mathrm{~L}$ & $\begin{array}{r}11.0 \mathrm{~L} @ 6,250 \text { rpm } 8.3 \mathrm{~L} \\
\text { estimated @7,500 rpm }\end{array}$ & $6.5 \mathrm{~L}$ \\
\hline $\begin{array}{c}\text { Weight } \\
\text { (17 lb. goal) }\end{array}$ & $18.8 \mathrm{lb}$ & $\begin{array}{c}19.6 \text { lb @ 6,250 rpm } \\
16 \text { lb estimated @7,500 rpm }\end{array}$ & $17.3 \mathrm{lb}$ \\
\hline $\begin{array}{l}\text { Cost Estimate } \\
\text { (Drawing Count) }\end{array}$ & $\begin{array}{l}12 \text { Fabrication Drawings } \\
4 \text { Purchased Drawings }\end{array}$ & $\begin{array}{l}30 \text { Fabrication Drawings } \\
4 \text { Purchased Drawings }\end{array}$ & $\begin{array}{l}13 \text { Fabrication } \\
\text { Drawings } \\
8 \text { Purchased } \\
\text { Drawings } \\
\end{array}$ \\
\hline Drive Efficiency & Main Crank Pin Bearing & Flank Length is $3-4 X^{\prime}$ 's & $\begin{array}{c}\text { Windage Loss } \\
\text { Shaft Seals } \\
\text { Low Speed Efficiency }\end{array}$ \\
\hline Noise & $\begin{array}{l}\text { Lower Speed } \\
\text { Ball Thrust Bearing }\end{array}$ & $\begin{array}{c}\text { Pulse Phasing of } 4 \text { Scrolls } \\
\text { Higher Speed }\end{array}$ & $\begin{array}{c}\text { No ball thrust } \\
\text { Bearings } \\
\text { Two Rotating Rotors }\end{array}$ \\
\hline Technical Risk & Medium & $\begin{array}{c}\text { Low-Medium } \\
\text { Proven Drive Mechanism }\end{array}$ & High \\
\hline
\end{tabular}


The results of the analyses presented in Table 4 can be summarized as follows:

- Single-Sided Orbiting Scroll Design (Conventional)

- Lowest Part Count

- Acceptable Size and Weight

- Acceptable Technical Risk

- Co-Rotating Design (Unconventional Drive)

- Smallest Size and Weight

- Acceptable Part Count

○ Best Potential for Low Speed Efficiency

- Quad Orbiting Design (Unconventional Drive)

- Best Thermal and Lubricant Isolation

- Potential Noise Advantage

- Demonstrated and Proven Design Configuration

\subsubsection{Technical Risk Assessment}

An assessment of the technical risk of each configuration was also conducted in order to gauge the likelihood of success for each approach. The results of this assessment are presented in Table 5.

Table 5: Results of Technical Risk Assessment

\begin{tabular}{|c|c|c|c|}
\hline Technical Risk & Single Orbiting Scroll & Quad Orbiting Scroll & Co-Rotation Scroll \\
\hline Lubricant Isolation & $\begin{array}{c}\text { Isolating Grease in } \\
\text { Thrust Bearing }\end{array}$ & Minimum Risk & Shaft Seal Failure \\
\hline $\begin{array}{c}\text { Thermal } \\
\text { Management }\end{array}$ & $\begin{array}{c}\text { Cooling Crank Pin } \\
\text { Bearing }\end{array}$ & $\begin{array}{c}\text { Cooling Fans Maybe } \\
\text { Required }\end{array}$ & Needle Bearings at Gas Temp. \\
\hline $\begin{array}{c}\text { Lubricant life \& } \\
\text { Service }\end{array}$ & $\begin{array}{c}\text { Re-Greasing Crank Pin } \\
\text { Bearing }\end{array}$ & Fully Isolated & Re-Greasing Needle Bearings \\
\hline $\begin{array}{l}\text { Volumetric } \\
\text { Efficiency }\end{array}$ & $\begin{array}{l}\text { Axial Deflection of } \\
\text { Orbiting \& Fixed Scroll }\end{array}$ & $\begin{array}{l}\text { - Long Flank Seal } \\
\text { Length } \\
\text { - Tolerance Stack Up }\end{array}$ & $\begin{array}{l}\text { - Deflections at High Speed } \\
\text { - Tip Seal Performance } \\
\text { - Shaft Seal Leakage }\end{array}$ \\
\hline $\begin{array}{c}\text { Mechanical Power } \\
\text { Loss }\end{array}$ & $\begin{array}{l}\text { - Main Crank Pin } \\
\text { bearing } \\
\text { - Grease Seal Friction }\end{array}$ & $\begin{array}{l}\text { - Multiple Bearings } \\
\text { - Grease Lube } \\
\text { - Grease Seal Friction }\end{array}$ & $\begin{array}{l}\text { - Windage Loss } \\
\text { - Shaft Seal Friction }\end{array}$ \\
\hline $\begin{array}{l}\text { Obtaining } 5000 \mathrm{hr} \\
\text { Life \& Maximum } \\
\text { Speed }\end{array}$ & $\begin{array}{l}\text { - Main Crank Pin } \\
\text { Bearing } \\
\text { - Tipping of Scroll } \\
\text { - Contact Stress on Balls } \\
\end{array}$ & $\begin{array}{l}\text { - Minimum Risk } \\
\text { - Higher Risk @ } 7250 \\
\text { rpm }\end{array}$ & $\begin{array}{l}\text { - Life of Timing Teeth } \\
\text { - Shaft Seals/Belts } \\
\text { - Deflection of Shaft }\end{array}$ \\
\hline $\begin{array}{l}\text { Costly Purchased } \\
\text { Parts Expensive } \\
\text { Fabricated Parts }\end{array}$ & Main Crank Bearing & $\begin{array}{l}\text { Conventional } \\
\text { Components }\end{array}$ & $\begin{array}{l}\text { - Belts } \\
\text { - Balancing } \\
\text { - Quill Shaft Fabrication }\end{array}$ \\
\hline
\end{tabular}

\subsubsection{Downselect Process}

A set of selection criteria was defined and used to create a decision matrix, which permitted efficient evaluation of the preliminary designs for the three configurations. The key evaluation criteria that were chosen for the selection of the scroll configuration are:

- Subsystem weight \& size 
- Subsystem cost

- Lubricant management

- Efficiency

- Noise

- Availability of successful predicate devices (technical risk)

This set of selection criteria was used along with the results of the analyses shown in Tables 4 and 5 to determine the most promising scroll configuration. A matrix was constructed to aid in the evaluation of the alternatives, in which each evaluation parameter was rated on a scale of 1 to 3 , with 1 being the worst and 3 being the best. The results of the decision matrix appear in Table 6.

Table 6: Scroll Configuration Decision Matrix

\begin{tabular}{|c|c|c|c|}
\hline $\begin{array}{c}\text { Evaluation } \\
\text { Parameter }\end{array}$ & Single Orbiting & $\begin{array}{c}\text { Single } \\
\text { Co-Rotating }\end{array}$ & Quad Orbiting \\
\hline Weight & 2 & 3 & 1 \\
\hline Size & 3 & 3 & 1 \\
\hline Cost & 3 & 2 & 1 \\
\hline Noise & 2 & 2 & 3 \\
\hline Efficiency & 3 & 2 & 3 \\
\hline Lubrication & 2 & 2 & 3 \\
\hline Technical Risk & 2 & 1 & 14 \\
\hline \hline Total & $\mathbf{1 7}$ & $\mathbf{1 5}$ & 2 \\
\hline
\end{tabular}

As a result of the evaluation process, the Single Orbiting Scroll configuration was selected as the most promising configuration with which to proceed. The major factors in the decision were the following:

- Low size and weight - though not the lowest, they were not far from being the lowest

- Significantly lower technical risk when compared to the smallest/lightest design

- Performance was acceptable and comparable with the other concepts

- Differences in noise were judged indistinguishable, with the Quad design having some potential advantages

\subsubsection{Single Orbiting Scroll}

The Single Orbiting Scroll, utilizing a conventional crank-driven orbital scroll, represents a conservative choice in the design of this system element, consistent with the overall need embodied in the program objectives to demonstrate the performance of the overall system concept. A solid model view of the Single Orbiting Scroll is presented in Figure 16. 


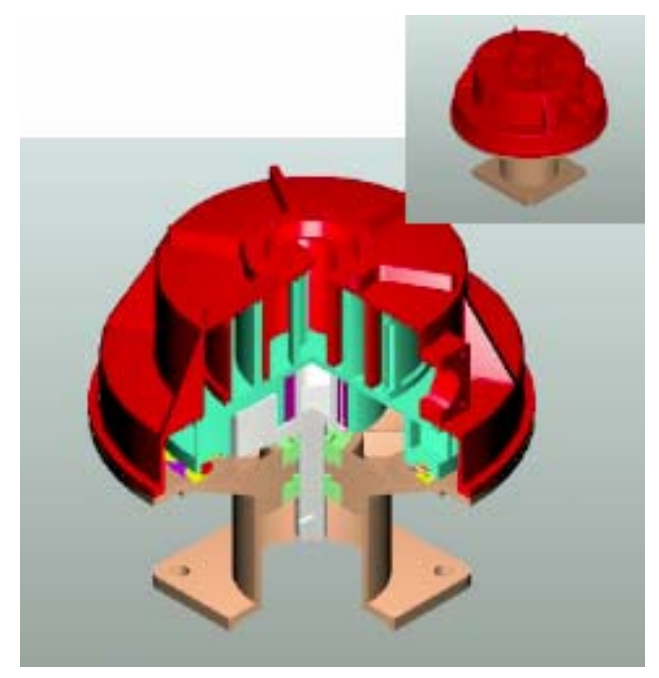

\section{Figure 16: Solid Model of Single Orbiting Scroll}

The single orbiting scroll design represents a low-risk approach, incorporating new and stringent lubricant management features into well-proven design configurations. A preliminary design of the scroll compressor was completed. The selected scroll compressor design uses a conventional crank-driven orbiting scroll, supported on a roller-Oldham thrust bearing system that is grease lubricated. This configuration has the substantial advantage of conventionality, enabling the direct utilization of knowledge gained in dozens of scroll compressor design programs. The most highly stressed machine element, the crank bearing, was selected and was to be tested in a fullscale brassboard drive mechanism demonstration device. This roller bearing is of conventional design, and grease lubricated. The lubricant for both the crank and thrust bearings is isolated from the process gas by three means: (1) the high viscosity and low volatility of the grease itself, (2) mechanical sealing of the process gas space form the lubricant space, and (3) pressure gradient isolation of any tramp lubricant from entering the process stream. Estimated compressor peak efficiencies of $70 \%$ are comparable with the efficiencies demonstrated in previous generations of scroll compressors, and indicate that the overall net shaft power consumption of the system will be approximately $5-6 \mathrm{~kW}$.

A number of design challenges for the Single Scroll Configuration were identified, and provided focus during the detail design effort.

- Maintenance of flank clearances over operating regime

- Tipping of scroll during transient conditions

- Lubrication of bearings

- Life of lubricant

- Lubricant isolation

- Cooling crank pin bearing

- Bearing cost

- Stiffness of scroll support structures

- Contact stress on Oldham/thrust balls and retainer 


\subsection{Intercooler Design}

The purpose of the intercooler is to provide rejection of the heat of compression of the turbocompressor. The intercooler between the turbocompressor and the scroll compressor has conventional performance requirements, and the preliminary approach was to select an available automotive intercooler of the appropriate size and integrate it into the system. An off-the-shelf intercooler was selected for the Hybrid CEM system and is shown in Figure 17. The figure also contains a representative scroll part to provide an indication of the relative size of the intercooler.

Several of the key performance features of the intercooler are as follows:

- The heat exchanger has excess heat rejection capability for our purposes

- Estimated turbo-compressor discharge conditions are as high as $215^{\circ} \mathrm{F}$ at a $2: 1$ pressure ratio

- Estimated reduction in inter-stage temperature to $120^{\circ} \mathrm{F}$ with intercooler

- Approximately $4 \mathrm{~kW}$ of heat of compression will have to be rejected to the ambient through the inter-cooler

- This heat rejection contributes to the fuel cell system heat rejection

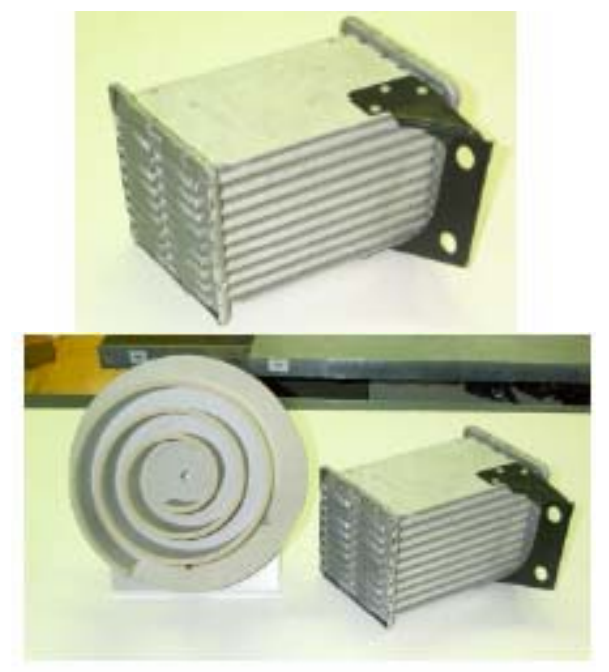

Figure 17: Selected Automotive Intercooler

\subsection{Control and Data Management}

The control and data management system configuration is dependent upon both the data acquisition requirements and the control measurement and actuation means configured into the individual subsystems. Design of the hardware and algorithms were to commence following the completion of the preliminary subsystem designs. The test regimen for the subsystems, and ultimately the system as a whole, were anticipated to represent not merely a data acquisition phase, but an integration, test and debugging phase. 


\subsection{Fabrication of Brassboard Drive Mechanism}

The first step in the prototype fabrication was to construct a brassboard to test the scroll drive mechanism. Figure 18 contains a photo of the test fixture for the brassboard drive mechanism.

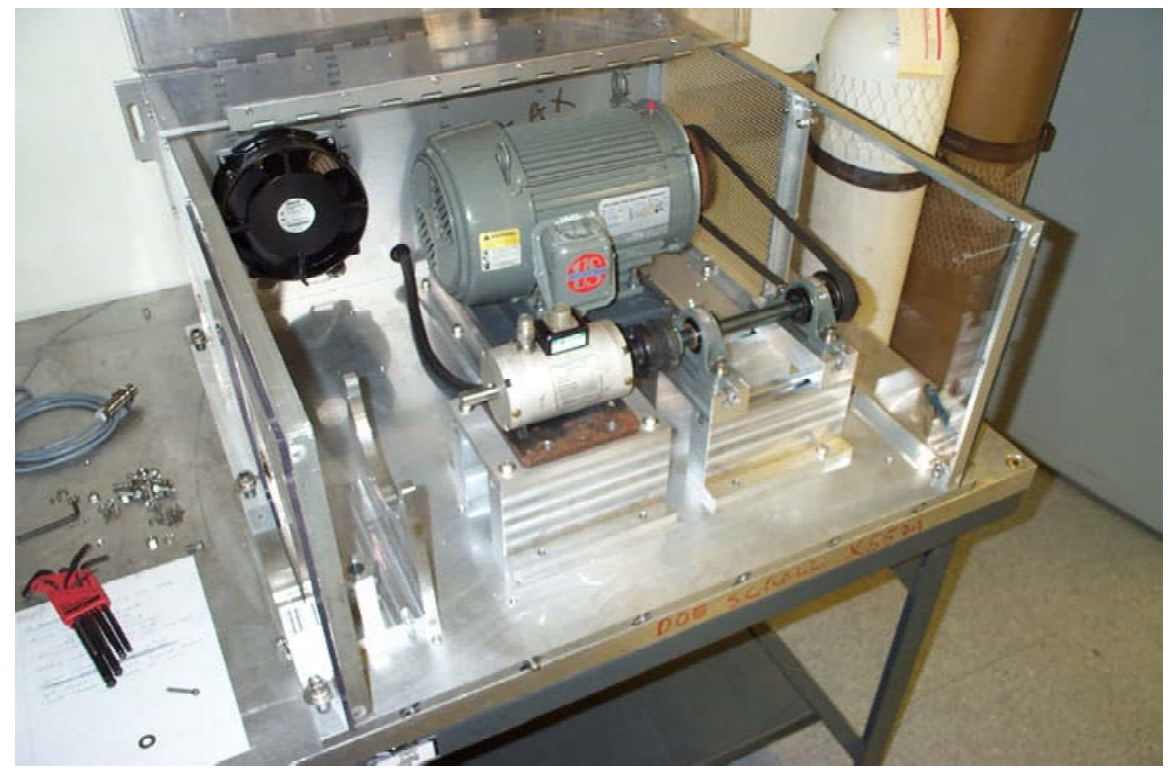

\section{Figure 18: Test Fixture for Brassboard Drive Mechanism}

The purpose of this fixture is to validate that the bearings and bearing support are sufficiently rigid to ensure that the scroll surfaces will remain in alignment when subjected to loading due to gas and centrifugal forces. The fabrication of the brassboard drive mechanism for the Hybrid CEM was done primarily at TIAX. The majority of the machined components were fabricated in TIAX's CNC machining center (see Figure 19 below). Inspection of internally and externally machined parts was planned with TIAX's CMM inspection machine. Assembly of the brassboard was planned to take place in the TIAX scroll laboratory. 

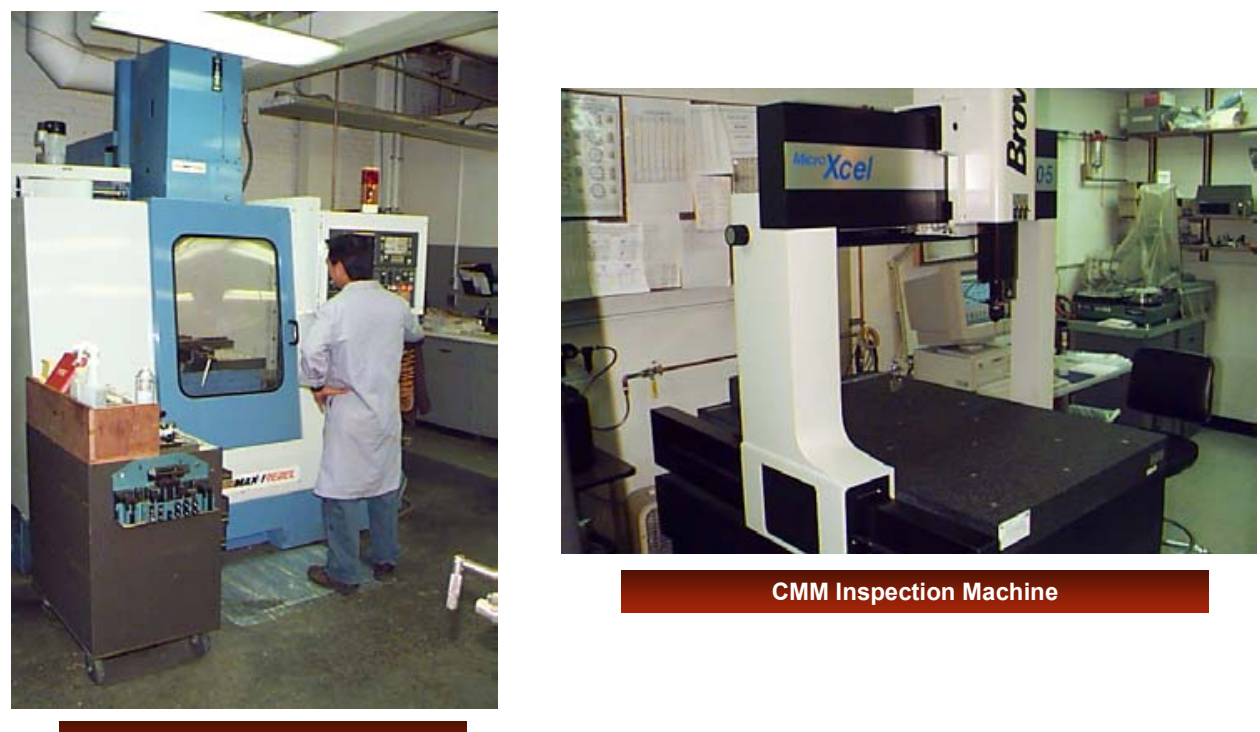

CMM Inspection Machine

CNC Machining Center

Figure 19: TIAX CNC Machining Center and CMM Inspection Machine

\subsection{Stop Work Order}

On 28 August, 2003, the DOE issued a stop work order for the Hybrid CEM program, effective at close of business on that day. The DOE indicated that this stop work order was related to FY 2004 funding constraints, and that in general they were satisfied with the performance on the program.

At that point in the program, the components for the brassboard drive mechanism were in the process of being fabricated. The effect on the program was that this fabrication effort was stopped midway, so that the brassboard was never assembled or tested. While our analyses indicated that the performance of the Hybrid CEM was very promising, we did not get the opportunity to validate the performance of the design by testing with physical hardware. 


\subsection{Results}

Based on the design and analyses conducted on the Hybrid CEM, the hybrid approach offers significant improvements relative to the all-scroll second generation CEM previously developed and tested, while maintaining scroll-enabled pressure/flow and turndown performance. The following tables contain the results of the detailed design and analyses of the Hybrid CEM, along with a comparison to the DOE guidelines and the performance of the Second Generation CEM.

Table 7: Comparison with DOE Guidelines - Compressor Performance

\begin{tabular}{|c|c|c|c|}
\hline Parameter & DOE Guidelines & $\begin{array}{c}2^{\text {nd }} \text { Generation Scroll } \\
\text { Performance }\end{array}$ & Hybrid CEM Targets \\
\hline $\begin{aligned} \text { Flow Rate: } & \text { Dry Air g/sec) } \\
& \text { Water Vapor (g/s) }\end{aligned}$ & $\begin{array}{l}65-75 \\
0 \text { to } 4\end{array}$ & $\begin{array}{c}61 \\
\text { See Note } 1 \\
\end{array}$ & $\begin{array}{l}67-76 \\
0 \text { to } 4\end{array}$ \\
\hline Stoichiometry & 2.0 & 2.0 & 2.0 \\
\hline $\begin{array}{l}\text { Inlet Pressure (atm) } \\
\text { Outlet Pressure (atm) }\end{array}$ & $\begin{array}{l}1.0 \\
3.2\end{array}$ & $\begin{array}{l}1.0 \\
3.2\end{array}$ & $\begin{array}{l}1.0 \\
3.2\end{array}$ \\
\hline $\begin{array}{l}\text { Inlet Temperature: } \\
\text { Design Point }\left({ }^{\circ} \mathrm{F}\right) \\
\text { Extreme Range }\left({ }^{\circ} \mathrm{F}\right)\end{array}$ & $\begin{array}{l}68 \text { to } 77 \\
-40 \text { to } 140\end{array}$ & $\begin{array}{c}60 \text { to } 80 \\
\text { See Note } 2\end{array}$ & $\begin{array}{l}68 \text { to } 77 \\
-40 \text { to } 150\end{array}$ \\
\hline $\begin{array}{l}\text { Maximum Shaft Power }(\mathrm{kW}) \\
\text { Turndown Ratio } \\
\text { Stages }\end{array}$ & $\begin{array}{c}12.6 \\
10: 1 \\
1 \text { or } 2\end{array}$ & $\begin{array}{c}13.0 \\
10: 1 \\
1\end{array}$ & $\begin{array}{c}\text { SC: } 6 \text { TC: 6 } \\
10: 1 \\
2\end{array}$ \\
\hline Contamination & Oil-free <100 ppm & $<50 \mathrm{ppm}^{3}$ & Grease-lubed \\
\hline $\begin{array}{ll}\text { Efficiency: } & \\
100 \% \text { flow } & 3.2 \mathrm{PR} \\
80 \% \text { flow } & 3.2 \mathrm{PR} \\
60 \% \text { flow } & 2.7 \mathrm{PR} \\
40 \% \text { flow } & 2.1 \mathrm{PR} \\
20 \% \text { flow } & 1.6 \mathrm{PR} \\
10 \% \text { flow } & 1.3 \mathrm{PR}\end{array}$ & $\begin{array}{l}75 \% \\
80 \% \\
75 \% \\
70 \% \\
65 \% \\
50 \%\end{array}$ & $\begin{array}{l}--- \\
71 \% \\
69 \% \\
64 \% \\
49 \% \\
52 \% \\
\end{array}$ & $\begin{array}{l}\text { SC:70\% TC:70\% } \\
\text { SC:70\% TC:75\% } \\
\text { SC:70\% TC:70\% } \\
\text { SC:65\% TC:65\% } \\
\text { SC:50\% TC:---- } \\
\text { SC:50\% TC:---- }\end{array}$ \\
\hline
\end{tabular}

Notes: ${ }^{1}$ Testing was done with dry air

${ }_{3}^{2}$ Extreme condition testing not performed

${ }^{3}$ Worst case estimate 
Table 8: Comparison with DOE Guidelines - Expander Performance

\begin{tabular}{|c|c|c|c|}
\hline Parameter & DOE Guidelines & $\begin{array}{c}2^{\text {nd }} \text { Generation Scroll } \\
\text { Performance }\end{array}$ & Hybrid CEM Targets \\
\hline $\begin{aligned} \text { Flow Rate: } & \text { Dry Air g/sec) } \\
& \text { Water Vapor (g/sec) }\end{aligned}$ & $\begin{array}{l}56-70 \\
9 \text { to } 16\end{array}$ & $\begin{array}{c}77 \\
\text { See Note } 1\end{array}$ & Input \\
\hline Stoichiometry & 2.0 & 2.0 & 2.0 \\
\hline $\begin{array}{l}\text { Inlet Pressure (atm) } \\
\text { Outlet Pressure (atm) }\end{array}$ & $\begin{array}{l}2.8 \\
1.0\end{array}$ & $\begin{array}{c}2.7 \text { to } 3.2 \\
1.0\end{array}$ & $\begin{array}{l}\text { Input } \\
\text { Input }\end{array}$ \\
\hline $\begin{array}{l}\text { Inlet Temperature: } \\
\text { Design Point }\left({ }^{\circ} \mathrm{F}\right) \\
\text { Extreme Range }\left({ }^{\circ} \mathrm{F}\right)\end{array}$ & $\begin{array}{l}244 \text { to } 302 \\
149 \text { to } 302\end{array}$ & $\begin{array}{l}84 \text { to } 289 \\
\text { See Note } 2\end{array}$ & Input \\
\hline $\begin{array}{l}\text { Maximum Shaft Power (kW) } \\
\text { Turndown Ratio } \\
\text { Stages }\end{array}$ & $\begin{array}{c}8.3 \\
10: 1 \\
1\end{array}$ & $\begin{array}{c}7.6 \\
10: 1 \\
1\end{array}$ & $\begin{array}{c}\sim 6 \\
10: 1 \\
1\end{array}$ \\
\hline $\begin{array}{ll}\text { Efficiency: } & \\
100 \% \text { flow } & 3.2 \mathrm{PR} \\
80 \% \text { flow } & 3.2 \mathrm{PR} \\
60 \% \text { flow } & 2.7 \mathrm{PR} \\
40 \% \text { flow } & 2.1 \mathrm{PR} \\
20 \% \text { flow } & 1.6 \mathrm{PR} \\
10 \% \text { flow } & 1.3 \mathrm{PR}\end{array}$ & $\begin{array}{l}90 \% \\
90 \% \\
86 \% \\
82 \% \\
80 \% \\
75 \%\end{array}$ & $\begin{array}{c}--- \\
81 \% \\
80 \% \\
77 \% \\
63 \% \\
74 \%\end{array}$ & $\begin{array}{l}86 \% \\
86 \% \\
86 \% \\
78 \% \\
60 \% \\
--\end{array}$ \\
\hline
\end{tabular}

Table 9: Comparison with DOE Guidelines - Overall Performance

\begin{tabular}{|c|c|c|c|}
\hline Parameter & DOE Guidelines & $\begin{array}{c}2^{\text {nd }} \text { Generation } \\
\text { Scroll } \\
\text { Performance }\end{array}$ & Hybrid CEM Targets \\
\hline $\begin{array}{l}\text { Maximum Overall Shaft } \\
\text { Power }(\mathrm{kW})\end{array}$ & 4.3 & 5.4 & 5.1 \\
\hline Volume $^{*}$ (liters) & 4 & 27 & 9 \\
\hline Weight* $^{*}(\mathrm{~kg})$ & 3 & 36.3 & $\sim 12$ \\
\hline Production Costs*@100,000 Units/Yr & $\$ 200$ & $\$ 355$ & $\$ 300-\$ 340^{8}$ \\
\hline Start-up Response & $<5$ s to $90 \%$ Max RPM & $0.82 \sec ^{6}$ & Stack capacity limited \\
\hline Transient Response & $\begin{array}{l}<4 \text { s for } 20 \% \text { to } 90 \% \\
\text { max flow }\end{array}$ & $0.72 \sec ^{6}$ & Stack capacity limited \\
\hline Noise $^{7}$ & $<80 \mathrm{db}$ & $\begin{array}{l}\text { 84dBA @40\% } \\
95 \mathrm{dBa} @ 80 \%\end{array}$ & Speculative \\
\hline
\end{tabular}

*Without heat exchangers or motors/controllers

${ }^{6}$ Calculated value

${ }^{7}$ Noise measured at one meter without mufflers

${ }^{8}$ Using proprietary and Boothroyd-Dewhurst ground-up costing 


\subsection{Conclusions}

The detailed design and analysis conducted on Hybrid CEM concept indicated no issues which would threaten the viability of the selected system architecture. A substantial degree of detailed system and component design work was required to fully explore the issues of practicality and performance, with the result that the design team still believes that the promise of thermodynamic performance substantially equal to that of the Second Generation Scroll CEM, at a substantially reduced weight and volume, is not only achievable, but within reach.

Based on detailed designs of the critical system elements, the Hybrid Compressor/Expander Module concept was projected to deliver significant improvements in weight, volume and manufacturing cost relative to previous generation systems. Further, based on analysis of the design, the parasitic power requirements of the system are also expected to improve. A novel system architecture substantially simplifies the overall system, permits flexible pressure/flow tailoring of the system behavior, and provides important improvements in manufacturability with minimal performance penalty provided that the small decrease in oxygen concentration in the feed gas is well tolerated by the fuel cell. Additional work was planned to finalize the design of the scroll compressor and turbomachinery and subsequently to fabricate hardware to demonstrate definitively the promise of the Hybrid CEM concept, but could not be implemented due to the termination of funding. 


\subsection{References}

1. "Advanced Fuel Cells for Transportation Applications (Development of Compressor/Expander for Fuel Cells in Transportation Applications", Final Report for DOE Contract DE-AC08-96NV11982, prepared by Arthur D. Little, February 10, 1998.

2. "Development of a Second Generation Scroll Compressor/Expander Module for Automotive Fuel Cell Application", Final Report for DOE Contract DE-FC0297EE50487, prepared by Arthur D. Little, December 22, 2000. 